\title{
PIOTR EBERHARDT
}

\section{LINIA CURZONA JAKO WSCHODNIA GRANICA POLSKI - GENEZA I UWARUNKOWANIA POLITYCZNE}

\section{Wprowadzenie}

Współczesna wschodnia granica Polski na długim odcinku między Karpatami na południu a Kanałem Augustowskim na północy przebiega w przybliżeniu według tzw. linii Curzona. Wiedza o tym fakcie jest powszechnie znana i odnotowana w każdej encyklopedii i podręczniku historycznym. W chwili rozpatrywania tego rozgraniczenia w sposób bardziej szczegółowy okazuje się , że w literaturze przedmiotu istnieje w tej kwestii wiele uproszczeń i przeinaczeń. Utrudnia to zrozumienie przyczyn i przesłanek podjętej decyzji granicznej, która zapadła na konferencji wielkich mocarstw $\mathrm{w}$ Teheranie, a następnie została ostatecznie zatwierdzona na konferencji w Jałcie. Ustalenia podjęte wówczas przez trzy wielkie mocarstwa koalicji antyhitlerowskiej nawiązywały w sposób jednoznaczny do propozycji, które były już formułowane po I wojnie światowej i ponownie zostały przypomniane oraz wprowadzone w życie po 25 latach w całkowicie nowych uwarunkowaniach geopolitycznych.

W polityce międzynarodowej aż do I wojny światowej nie brano pod uwagę możliwości odtworzenia niepodległego państwa polskiego. W takiej sytuacji projekty odniesione do przyszłych granic niepodległej Polski były uważane za postulaty dość abstrakcyjne i odległe od realiów współczesnego porządku europejskiego. O niewielkim zainteresowaniu państw europejskich aspiracjami niepodległościowymi Polaków świadczy reakcja na wyłączenie w 1912 r. z tzw. Królestwa Polskiego utworzonej przez carat guberni chełmskiej. Pomimo że było to ewidentne pogwałcenie werdyktu Kongresu Wiedeńskiego, poza opinią polską, która zareagowała na tę decyzję władz carskich dość emocjonalnie, problem ten nie wzbudził większego zainteresowania nawet u władz dwóch pozostałych państw zaborczych. Traktowano to jako podrzędną kwestię będącą w kompetencji rządu rosyjskiego ${ }^{1}$.

Społeczeństwo polskie zdawało sobie sprawę z realiów ówczesnej sytuacji politycznej. Liczono jedynie na wojnę europejską, która jest w stanie wiele zmienić i dlatego ukształtowały się dwie orientacje, opierające swoje nadzieje na zwycięstwie państw

${ }^{1}$ L. Dymsza, Sprawa chetmska, Warszawa 1911, s. 2. 
centralnych, względnie Ententy. Pomimo że uzyskanie przez Polskę suwerenności było odległym mirażem, trudnym do wyobrażenia, liczni polscy historycy, geografowie lub działacze polityczni zakładali, że to marzenie w bliższej lub dalszej perspektywie zostanie urzeczywistnione. W takiej sytuacji na porządku dnia stanie kwestia ustalenia granic wskrzeszonego z niebytu państwa polskiego.

Poglądy Polaków na zasięg terytorialny tzw. ziem polskich w ciągu całego XIX wieku były jednoznaczne. Jedynym sprawiedliwym, satysfakcjonującym rozwiązaniem musi być powrót do granic historycznych Rzeczypospolitej. Idea restytucji Rzeczypospolitej w granicach z 1772 r. stanowiła program oczywisty, niewzbudzający większych kontrowersji. Aż do przełomu XIX i XX wieku bagatelizowano kwestie składu narodowościowego, językowego czy religijnego ziem historycznej Rzeczypospolitej. Zdawano sobie sprawę $\mathrm{z}$ występujących różnic między Koroną, Litwą i Rusią. Zakładano, że utrzymująca się przez stulecia wspólnota ideowa spajająca ludy Rzeczypospolitej nadal istnieje ponad kordonami granicznymi narzuconymi przez zaborców. Różnice regionalne nie odgrywają większej roli, a ewentualne porozumienie o charakterze federacyjnym tę kwestię rozwiąże w sposób bezkonfliktowy. Przewidywano, że wschodnią granicą odrodzonej Polski będzie Dniepr i Berezyna, a każde inne rozwiązanie będzie rozstrzygnięciem niesprawiedliwym.

W miarę szybko zmieniających się warunków politycznych oraz demograficzno-narodowościowych postulat ten stawał się coraz mniej oczywisty. W mniejszym stopniu wpłynęły na to uwarunkowania zewnętrzne. Większą rolę odegrały zmiany postaw świadomościowych wśród ludności zamieszkującej Kresy Wschodnie. Nowe idee narodowe na tym obszarze wykrystalizowały się stosunkowo późno. Wiązało się to z niskim poziomem wykształcenia mas ludowych oraz brakiem lokalnych elit nawiązujących do chłopskich tradycji. W ciągu kilku wieków istnienia I Rzeczypospolitej warstwy wyższe uległy polonizacji i wytworzyły jeden naród szlachecki. Były one związane z kulturą i językiem polskim i kultywowały spuściznę jednolitego państwa. Opcja identyfikacyjna w obrębie warstwy chłopskiej zaczęła się stopniowo wykształcać w końcu XIX wieku. W momencie dotarcia do ludności Kresów Wschodnich haseł narodowościowych jednolite dotychczas ziemie między Bugiem a Dnieprem zaczęły się stopniowo różnicować pod względem narodowościowym. Przyniosło to w rezultacie podział terytorium historycznej Rzeczypospolitej na obszary o odrębnym charakterze etnicznym (polskie, ukraińskie, rusińskie, białoruskie, litewskie, łotewskie). Granice między obszarami polskimi i niepolskimi nie zawsze były czytelne. Istniały szerokie pogranicza, gdzie żyli mieszkańcy, którzy mieli kłopoty ze swym samookreśleniem narodowym. Pojawiały się zwłaszcza tam, gdzie rozgraniczenia zasięgów religijnych nie były zbieżne z lingwistycznymi.

Przed środowiskiem polskich uczonych i działaczy niepodległościowych pojawił się niezmiernie istotny dylemat. Miał on nie tyle oblicze naukowe, ile polityczne. Powstały dwa pojęcia tzw. Polski historycznej oraz tzw. Polski etnicznej². Oba znacznie się od

2 Problematykę tę na podstawie obszernej literatury przedmiotu przedstawiono w książce: R. Wapiński, Polska i małe ojczyzny Polaków, Wrocław-Warszawa-Kraków 1994. 
siebie różniły. Czołowi polscy geografowie (W. Pol, W. Nałkowski, E. Romer) nadal byli przekonani, że do obszarów położonych między etniczną Polską a etniczną Rosją naród polski ma pełne prawa polityczne. Uzasadniali to argumentami historycznymi, kulturowymi, społecznymi i ekonomicznymi. Dotychczasową granicę między tzw. Królestwem Polskim a tzw. „obszarami zabranymi” traktowano jako barierę sztuczną, narzuconą siłą przez carat rosyjski. Likwidacja tej granicy i połączenie obu podzielonych obszarów jest warunkiem naprawienia krzywdy dziejowej.

W latach poprzedzających wybuch I wojny światowej zaczęto przywiązywać coraz większą rolę aspektom etnicznym i zasadom subiektywnego samookreślenia. Wiedza o sytuacji językowej i religijnej, początkowo fragmentaryczna, stawała się coraz bardziej klarowna. Zaczęły się pojawiać prace demografów ukraińskich, białoruskich i litewskich kwestionujących idee odtworzenia Rzeczypospolitej. Stając się orędownikami aspiracji swoich narodów, krytycznie oceniali dokonania cywilizacyjno-kulturowe Polski. W odpowiedzi badacze polscy uwypuklali polityczne i społeczne znaczenie miejscowej ludności polskiej. Pojawiły się znaczące kontrowersje w kwestii liczebności i rozmieszczenia poszczególnych narodowości ${ }^{3}$.

Różnica w rozległości terytorialnej „historycznej” i „etnicznej” Polski była niezwykle duża, gdyż obszar zamieszkały w sposób zwarty przez ludność narodowości polskiej był trzy-, a nawet czterokrotnie mniejszy od obszaru historycznej I Rzeczypospolitej. Zaczęto zdawać sobie sprawę, że powrót do granic przedrozbiorowych staje się nierealny ze względu na formujące się układy etniczne. W rezultacie musiało to doprowadzić do coraz większych rozbieżności w poglądach odniesionych do postulowanego kształtu terytorialnego odrodzonego w przyszłości państwa polskiego. Obok koncepcji dalej nawiązującej do granic wschodnich I Rzeczypospolitej pojawiły się projekty utworzenia niewielkiego państwa narodowego, którego granice wschodnie docierałyby do Bugu i Sanu (B. Wysłouch), a nawet rezygnacji z Chełmszczyzny (Cz. Jankowski). Zazwyczaj jednak tworzono pośrednie programy terytorialne, w których przyłączano do przyszłej Polski mieszane narodowościowo obszary o znacznej liczbie Polaków (zachodni Wołyń i Podole, Wileńszczyznę czy Mińszczyznę), rezygnując z obszarów położonych bardziej na wschodzie .

Wybuch I wojny światowej uaktywnił polskich badaczy, którzy zaczęli przewidywać, że sytuacja polityczna w całej Europie Środkowo-Wschodniej ulegnie przeobrażeniom i sprawa Polski nabierze znaczenia międzynarodowego. Równocześnie państwa zaborcze ze względów doraźnych zaczęły składać mniej lub bardziej spójne obietnice, w których było miejsce dla niewielkiej autonomicznej lub satelickiej Polski. Władze

${ }^{3}$ Można podać jako przykład, że Wileńszczyzna była ujmowana jako etniczny obszar polski, litewski, względnie białoruski. Zależało to od narodowości badacza. Ta kwestia została omówiona w artykule: M. Kowalski Wileńszczyzna jako problem geopolityczny, w: Problematyka geopolityczna ziem polskich, red. P. Eberhardt, „Prace Geograficzne” nr 218, Warszawa 2008, s. 267-296.

${ }^{4}$ Wiele informacji o licznych projektach badaczy polskich odniesionych do postulowanych granic państwa polskiego znajduje się w pracy autora: P. Eberhardt, Polska i jej granice. Z historii polskiej geografii politycznej, Lublin 2004, s. 37-119. 
niemieckie po oczekiwanym zwycięstwie skłaniały się dołączyć do okrojonego na zachodzie Królestwa Kongresowego pewne nieokreślone obszary zabużańskie. Władze rosyjskie widziały Polskę w granicach Cesarstwa Rosyjskiego. Miała ona uzyskać nabytki terytorialne kosztem Niemiec i Austrii. Polscy badacze zaczęli dostrzegać możliwość likwidacji kordonów zaborczych i zjednoczenia ziem polskich. W takiej sytuacji uzasadnienie sensowności wytyczenia takich czy innych granic politycznych przyszłej Polski nabierało aktualności. W związku z tym powstało kilka koncepcji autorskich odniesionych do tego kluczowego problemu determinującego pozycję Polski na mapie politycznej Europy (W. Wakara, W. Skargi-Dobrowolskiego, A. Szelągowskiego, J. Jaskólskiego). Różniły się one znacznie między sobą w kwestiach zasadniczych i szczegółowych. Miały one jedynie charakter symboliczny, gdyż nie stały za nimi żadne siły polityczne. Zupełnie inna sprawa wiązała się z koncepcjami terytorialnymi, które prezentował w późniejszym czasie R. Dmowski na posiedzeniach konferencji pokojowej w Wersalu. Były one rozpatrywane przez wielkich tego świata i odegrały istotną rolę polityczną ${ }^{5}$.

W rezultacie nieoczekiwanej klęski wszystkich trzech państw zaborczych w listopadzie 1918 r. powstała nowa odrodzona Polska. Granice nowego państwa formowały się przez trzy lata. Rozgraniczenie polityczne polsko-niemieckie ustalił traktat pokojowy zawarty w czerwcu 1919 r. w Wersalu przez państwa zwycięskiej koalicji z pokonanymi Niemcami. Wschodnia granica Polski była uzależniona od wyniku nieuniknionego konfliktu militarnego między Polską a bolszewicką Rosją. Klęska Polski byłaby końcem jej suwerennego bytu narodowego, skala zaś zwycięstwa mogła mieć istotny wpływ na przebieg granicy między obu zmagającymi się przeciwnikami. Możliwości ingerencji mocarstw zachodnich były dość ograniczone. Nie były one zainteresowane totalną porażką Polski, z drugiej zaś strony dość krytycznie podchodziły do bardziej maksymalistycznych dezyderatów granicznych Polski. Stosunek mocarstw Ententy do wschodniej granicy Polski nie był stały, z tym że Francja sprzyjała i rozumiała interesy Polski, Brytyjczycy zaś, a zwłaszcza premier Lloyd George, odnosili się nieprzyjaźnie i starali się ograniczyć aspiracje terytorialne państwa polskiego.

\section{Projekt linii Curzona jako wschodniej granicy Polski po I wojnie światowej}

W końcowej fazie I wojny światowej postulat odrodzenia państwa polskiego stawał się coraz bardziej realny. Klęska armii carskiej oraz dwie rewolucje, które kolejno wybuchły w Rosji, wyłączyły wschodniego zaborcę z polityki europejskiej. Nowe ugrupowania, które doszły do władzy w Rosji, pogodziły się w dużym stopniu z nieuniknioną stratą Królestwa Polskiego, które już od 1915 r. było okupowane przez państwa centralne. Te ostatnie nie były w stanie pokonać państw Ententy. Decydującą rolę w nowym powojennym porządku europejskim miała odgrywać Francja, Wielka Brytania i Stany Zjednoczone. Wszystkie te państwa stopniowo uznały prawa Polski do suwerenności i bezpiecznych granic tak na zachodzie, jak

${ }^{5}$ R. Dmowski, Polityka polska i odbudowanie państwa, t. I i II, Hanower 1947. 
i na wschodzie. Wyłączenie sojuszniczej carskiej Rosji z wojny ułatwiło mocarstwom zachodnim postawienie postulatu utworzenia niepodległej Polski. Kolejne deklaracje formułowane przez państwa Ententy były coraz bardziej konkretne i obligujące. Jedna z pierwszych uchwalona 3 grudnia 1917 r. brzmiała „utworzenie Polski niepodległej i niepodzielnej w warunkach zapewniających jej swobodny rozwój polityczny i ekonomiczny stanowi jeden z warunków trwałego i sprawiedliwego pokoju w Europie". Następna wypowiedź francuskiego ministra spraw zagranicznych Stéphena Pichona z 12 grudnia 1917 r. była zbliżona co do treści: „Chcemy Polski jednej, niepodległej, niepodzielnej z wszelkimi gwarancjami swobodnego rozwoju politycznego, gospodarczego, militarnego z wszelkimi konsekwencjami, jakie stąd mogą wyniknąć". Następne oświadczenie w imieniu Wielkiej Brytanii złożył jej premier Lloyd George w swym przemówieniu wygłoszonym 5 stycznia 1918 r.: „Sądzimy, że niepodległa Polska, obejmująca wszystkie rdzennie (genuinely) polskie żywioły (elements), które chcą wejść w jej skład stanowi pilną potrzebę dla stabilizacji zachodniej Europy"6.

W deklaracji tej uwypuklono zwrot o „rdzennie polskich żywiołach”. Ta wypowiedź wskazuje, że premier brytyjski optuje wyraźnie za „etniczną” Polską. Był tej koncepcji konsekwentnie wierny, będąc w późniejszych czasach orędownikiem linii Curzona jako wschodniej granicy Polski.

Dalsze przełomowe wydarzenie wiąże się z deklaracja wydaną 3 czerwca $1918 \mathrm{r}$. z okazji konferencji międzysojuszniczej trzech głównych państw Ententy, czyli Francji, Wielkiej Brytanii oraz Włoch, w której zapowiedziano utworzenie po wygranej wojnie niepodległego państwa polskiego. Ze względu na coraz większe znaczenie polityczne Stanów Zjednoczonych ważne było stanowisko prezydenta Woodrowa Wilsona. Z tego też powodu w sierpniu 1918 r. do Stanów Zjednoczonych udał się Dmowski, który wraz z Paderewskim przeprowadził rozmowę z Wilsonem. W trakcie tego spotkania przedstawiono postulaty terytorialne Polski. Najważniejszy z nich to swobodny dostęp do morza oraz włączenie w skład państwa polskiego nie tylko całego zaboru pruskiego, lecz także części Górnego Śląska i Prus Wschodnich. Zarysowano również projekt nowej wschodniej granicy Polski. W dostarczonym po rozmowie memoriale z odpowiednią mapą zostały zaprezentowane żądania terytorialne Polski na wschodzie. Była w nich zawarta pierwsza wersja tzw. linii Dmowskiego. Według tej propozycji poza włączeniem do Polski całej Galicji proponowano dokonanie podziału wschodnich prowincji I Rzeczypospolitej. Część zachodnia tego dużego terytorium, „gdzie żywioł polski jest liczniejszy i gdzie wpływ polski jest stanowczo przeważający”, powinien należeć do Polski. Strona polska rezygnowała natomiast ze wschodniej części Białorusi, Wołynia, Podola i Polesia. Granica wschodnia Polski miała przebiegać od Dyneburga na północy po Kamieniec Podolski na południu. Do

\footnotetext{
${ }^{6}$ Klasycznym dziełem w polskiej literaturze przedmiotu jest książka T. Piszczkowskiego, w której autor cytuje wyjątki najważniejszych dokumentów: T. Piszczkowski, Odbudowanie Polski 1914-1921. Historia i polityka, Londyn 1969, s. 106.
} 
tej propozycji Wilson odniósł się przychylnie, ale nie miało to wówczas większego znaczenia politycznego ${ }^{7}$.

Po ostatecznej klęsce państw centralnych nowy porządek europejski miała ustalić konferencja pokojowa powołana przez mocarstwa zwycięskie. Rozpoczęła ona swoją działalność w Paryżu 18 stycznia 1919 r., powołując Radę Najwyższą, w której znaleźli się przedstawiciele Stanów Zjednoczonych, Wielkiej Brytanii, Francji, Włoch i Japonii. Do udziału zaproszono inne państwa sprzymierzone, $\mathrm{w}$ tym Polskę, która uzyskała prawo delegowania dwóch przedstawicieli. Utworzono kilka komisji terytorialnych, w tym do spraw polskich, której przewodniczył dyplomata francuski Jules Cambon ${ }^{8}$.

Problem polskiej granicy wschodniej nie był na Konferencji Wersalskiej obiektem większego zainteresowania. Propozycje i sugestie, jakie w tym zakresie były podejmowane, nie miały charakteru wiążącego. Delegacja polska początkowo lansowała tezę o potrzebie powrotu Polski do granic przedrozbiorowych. Było to proponowane ze względów taktycznych, zdawano sobie bowiem sprawę z ich nierealności. Stanowisko polskie zostało zaprezentowane 29 stycznia 1919 r. przez Dmowskiego. W tym ważnym i doskonale umotywowanym wystąpieniu zostały przedstawione graniczne postulaty. Dotyczyły głównie wytyczenia polskiej granicy zachodniej. Zarysowano również uwarunkowania geopolityczne istniejące na styku interesów Polski oraz bolszewickiej Rosji.

Rada Najwyższa Sprzymierzonych sprawę granic Polski przekazała do dalszego rozpatrzenia i przygotowania konkretnych propozycji wspomnianej Komisji Cambona. Dla niej delegaci polscy przygotowali również odpowiednie uzasadnienie w kwestii wschodniej granicy Polski. Memoriał ten wystosowany 3 marca 1919 r. składał się z dwóch części. W pierwszej wstępnej przedstawiono charakterystykę ziem polskich zagarniętych przez Rosję, natomiast w części drugiej umieszczono polskie żądanie terytorialne. Proponowano włączenie do Polski obszarów przygranicznych ograniczonych od północy i wschodu długą linią graniczną przebiegającą od Wybrzeża Bałtyckiego w rejonie Libawy aż do Karpat ${ }^{9}$.

W memoriale o terytorium państwa polskiego złożonego przez Dmowskiego prezydentowi Stanów Zjednoczonych żądania polskie ujęte były następująco: „Terytorium polskie na wschód od Królestwa Polskiego winno by obejmować pozostałą, większą część Guberni Wileńskiej (włączając miasto Wilno) i Gubernię Grodzieńską, gdzie Polacy są w większości albo w bardzo znacznej mniejszości, większą część Guberni Mińskiej, obejmującej miasta Mińsk, Słuck i Pińsk, część zachodnią Podola (Płoskirów i Kamieniec Podolski)" (R. Dmowski, op. cit., t. II, s. 159-160).

${ }^{8}$ Obrady Konferencji Wersalskiej doczekały się obszernej literatury przedmiotu. Nie ma potrzeby jej przytaczania. Liczne na ten temat informacje znajdują się w opracowaniach zawierających oryginalne dokumenty: K. W. Kumaniecki, Odbudowa państwowości polskiej. Najważniejsze dokumenty 1912 - styczeń 1924, Kraków 1924; Stosunki polsko-radzieckie w latach 1917-1945: dokumenty i materiały, red. T. Cieślak, oprac. E. Basiński, Warszawa 1967.

${ }_{9} \mathrm{Na}$ podstawie własnoręcznie napisanej przez Dmowskiego noty z 3 marca 1919 r. można określić w sposób precyzyjny dezyderaty terytorialne Polski na wschodzie, które później przyjęły nazwę tzw. linii Dmowskiego: „Poczynając od Bałtyku granica wschodnia miała przebiegać: od wybrzeża na północ od Libawy granica postępuje na wschodzie linią historycznej granicy 1772 pomiędzy Polską a Kurlandią. Dochodzi w ten sposób do powiatu iłłuksztańskiego w Kurlandii. Powiat ten rewindykowany jest przez 
Propozycja ta od jej twórcy przyjęła nazwę linii Dmowskiego. Później uległa ona weryfikacji w części północnej, gdyż włączenie Litwy stawało się problematyczne. Projekt ten był prezentowany przez delegatów polskich w trakcie obrad wersalskich, ale stosunkowo szybko stracił aktualność i traktowany był jako dowód imperialnych roszczeń polskich.

Określenie stanowiska w odniesieniu do przebiegu polskiej granicy wschodniej było przedmiotem dyskusji prowadzących w Podkomisji do Spraw Polskich kierowanej przez gen. Henri Le Ronda. Rozpoczęła ona pracę 20 marca 1919 r. Do końca marca odbyło się pięć posiedzeń tej Podkomisji, 7 kwietnia 1919 r. miało zaś miejsce ostatnie spotkanie, na którym przyjęto ustalenia przekazane Komisji do Spraw Polskich na ręce jej przewodniczącego Julesa Cambona. Na ich podstawie Komisja przyjęła 22 kwietnia 1919 r. ostateczną propozycję graniczną. Przygotowany przez nią raport głosił: „Komisja jednomyślnie podjęła decyzję co do przyjęcia następujących ustaleń: 1/ zaaprobowania linii określonej w załączniku pierwszym do tego raportu jako wschodniej granicy Polski, idącej od dawnej granicy pomiędzy Prusami Wschodnimi a Rosją aż do punktu na wschód od Chełma"10. Przedstawione rozgraniczenie było zgodne w zasadzie z późniejszą „linią Curzona”, tyle że nie zajmowało stanowiska wobec podziału Galicji. Zaproponowana linia demarkacyjna miała więc charakter tymczasowy, gdyż zamierzano ją wytyczyć w porozumieniu z przyszłym rządem „białej” Rosji, która będzie prawnym spadkobiercą przedrewolucyjnego państwa będącego sojusznikiem państw Ententy. Przyszła Rosja miała mieć w tej sprawie głos decydujący ${ }^{11}$. Postanowienie tak niekorzystne dla Polski wynikało z faktu, że 9 marca

Polskę ze względu na swoją pozycję geograficzną i na przewagę w ludności elementu polskiego. Tutaj granica idzie brzegiem powiatu iłłuksztańskiego do rzeki Dźwiny i przechodzi na jej prawy brzeg (gubernia witebska), żeby postępować ku wschodowi równolegle do rzeki, a w odległości około 30 kilometrów do granic powiatu drysieńskiego, włączając tenże wraz z powiatem połockim. Dalej przechodzi ona na północny zachód do Horodka, powraca na lewy brzeg Dźwiny około 30 kilometrów od Witebska i idzie ku południowi, przechodząc na zachód od Sienna do punktu, w którym spotyka granicę pomiędzy gubernią mińską i mohylewską, postępując tą linią graniczną ku południowi aż do Berezyny w miejscu, gdzie ona dotyka granicy północnej powiatu rzeczyckiego, następnie przekraczając Berezynę, idzie w kierunku południowo-zachodnim do Prypeci na wschód od Mozyrza. Stamtąd przekraczając Prypeć granica idzie linią podziału pomiędzy powiatami mozyrskim i rzeczyckim, poczem, postępując ciągle w kierunku południowo-zachodnim przechodzi na zachód od miasta Owrucza i Zwiahla na Wołyniu i dochodzi do punktu, gdzie spotykają się granice powiatów zasławskiego, ostrogskiego i zwiahelskiego. Następnie kierując się na południe linia graniczna postępuje granicą wschodnią powiatu zasławskiego i staro-konstantynowskiego aż do punktu, gdzie spotyka granice powiatów latyczowskiego i płoskirowskiego na Podolu; stamtąd ciągle w kierunku południowym dosięga ona koło Zińkowa rzekę Uszycę i idzie z jej biegiem do Dniestru, który stanowi w tem miejscu południową granicę pomiędzy Polską i Rumunią" (R. Dmowski, op. cit., t. II, s. 167-168).

${ }^{10}$ L. Wyczelski, O Polsce $w$ Wersalu, Toruń 2008, s. 114.

${ }^{11}$ Określenie zachodniej granicy Rosji było dla mocarstw zachodnich kwestią dość złożoną z punktu widzenia prawa międzynarodowego. Wpływało to na postawę tych państw wobec polskiej granicy wschodniej. Dmowski zwracał na tę sprawę uwagę w swojej znanej książce: „Stanęła przede wszystkim poważna wątpliwość, czy Konferencja Pokojowa może ustanawiać granice między Polską a Rosją w nieobecności Rosji. Rosja nie była państwem zwyciężonym, przeciwnie, należała do koalicji wojującej z państwami 
1919 r. Rosyjska Rada Polityczna w Paryżu przedłożyła Konferencji Pokojowej notę domagającą się pozostawienia Rosji całkowitego prawa podejmowania decyzji co do przyszłości terytoriów należących do niej przed 1914 r. W rezultacie presji sojuszników zachodnich uczyniono wyjątek dla dziesięciu guberni Królestwa Polskiego (z wyłączeniem guberni suwalskiej). Równocześnie Rada Najwyższa Sprzymierzonych przyjęła 9 i 10 kwietnia 1919 r. deklarację od Rosyjskiej Rady Politycznej, w której stwierdzono, że na terenie wschodniej Galicji zamieszkują w większości Rosjanie, którzy domagają się przyłączenia do Rosji. Przedstawiciele „białej” Rosji traktowali bowiem Ukraińców i Białorusinów jako część narodu rosyjskiego. W ówczesnej sytuacji nie było wiadomo, jak się potoczą losy wojny domowej w Rosji i Podkomisja gen. Le Ronda nie była w stanie przewidzieć, „czy Polska w Galicji Wschodniej będzie graniczyła z Ukrainą czy też z Rosją, a jeśli z Rosją, to przez kogo rządzoną" ${ }^{12}$.

Sytuację polityczną komplikował fakt, że od końca 1918 r. ziemie wschodniej Galicji były miejscem zaciętego konfliktu militarnego między odrodzoną Polską a Zachodnio-Ukraińską Republiką Ludową (ZURL). Na przełomie 1918 i 1919 r. front polsko-ukraiński ustabilizował się na górnym Sanie, lecz Lwów wraz z linią kolejową Przemyśl-Lwów był opanowany przez Polaków. Mocarstwa zachodnie były zainteresowane zawieszeniem broni między obu walczącymi stronami, gdyż mogło to wzmocnić front antybolszewicki. $\mathrm{Z}$ tego powodu 15 lutego $1919 \mathrm{r}$. utworzono odpowiednią komisję rozjemczą, której przewodniczył gen. Joseph Barthélemy. Udał się on do Galicji, ale jego misja rozjemcza zakończyła się niepowodzeniem. Rezultatem jego działań była propozycja podziału spornego terytorium przedstawiona 22 lutego we Lwowie przedstawicielom Polski i ZURL. Według tego projektu Lwów oraz Zagłębie Naftowe (Borysławsko-Drohobyckie) miało pozostać po stronie polskiej, Tarnopol i Stanisławów zaś po stronie ukraińskiej. Granica miała przebiegać wzdłuż Bugu do miejscowości Kamionka Strumiłowa, następnie wytyczono ją $20 \mathrm{~km}$ na wschód od Lwowa, a na odcinku południowym pozostawiono Bóbrkę po stronie zachodniej. W tym samym czasie Ukraińcy żądali dla siebie Jarosławia, Przemyśla, Sanoka i Leska. Projekt zawieszenie broni i ustalenia linii rozjemczej według projektu Barthélemy’ego nie został zaakceptowany przez rząd ZURL. W takiej sytuacji strona polska zaproponowała w końcu lutego ustalenie linii rozjemczej łączącej Sokal-Busk-

centralnymi ... Trzymając się wszakże zbyt ściśle tego stanowiska, niepodobna byłoby ustanowić państwa polskiego, główna bowiem, środkową część Polski, dawne Królestwo Kongresowe, Rosja także zaliczała za milczącą zgodą mocarstw do swego terytorium państwowego. Wprawdzie rząd tymczasowy rosyjski w r. 1917 uznał niepodległość Polski, ale granicy między nią a Rosją nie przeprowadził... Prezydium konferencji wprawdzie zażądało od delegacji polskiej przedstawienia jej żądań w sprawie granicy wschodniej cośmy uczynili [tu autor mówi o tzw. linii Dmowskiego], ale dyskusji z nami w przedmiocie tych żądań nie podejmowano. Myśmy też zrozumieli, że tę sprawę zdecyduje przyszłość, zależnie od tego, jakie będą dalsze losy Rosji, że musi być ona załatwiona przede wszystkim między nami a Rosją. Później dopiero mocarstwa zrobiły próbę ustanowienia minimalnej granicy polskiej na wschodzie w postaci tzw. linii Curzona" (R. Dmowski, op. cit., t. II, s. 47).

12 P. P. Żurawski vel Grajewski, Sprawa ukraińska na konferencji pokojowej w Paryżu w roku 1919, Warszawa 1995, s. 25. 
-Halicz-Kałusz-Karpaty, którą kilka miesięcy później Piłsudski nieznacznie przesunął na zachód do linii Sokal-Busk-Kałusz-Karpaty. Oba te warianty włączały Lwów do Polski. Nie były więc przyjęte przez stronę ukraińską.

Rada Najwyższa Sprzymierzonych w celu zakończenia konfliktu polsko-ukraińskiego powołała 2 kwietnia 1919 r. Międzyaliancką Komisję Rozjemczą, na czele której stanął gen. Louis Botha. Przygotowała ona tzw. konwencję pokojową, w której określono linię rozejmową. Nie przesądzała ona przyszłej granicy między obu państwami. W stosunku do poprzedniej linii Barthélemy’ego była nieznacznie przesunięta na zachód, gdyż zagłębie Drohobycko-Borysławskie pozostawało po stronie ukraińskiej ${ }^{13}$ (ryc. 1).

Ryc. 1. Linia rozgraniczenia Galicji według gen. Barthélemy’ego i gen. Bothy’ego z 1919 r.

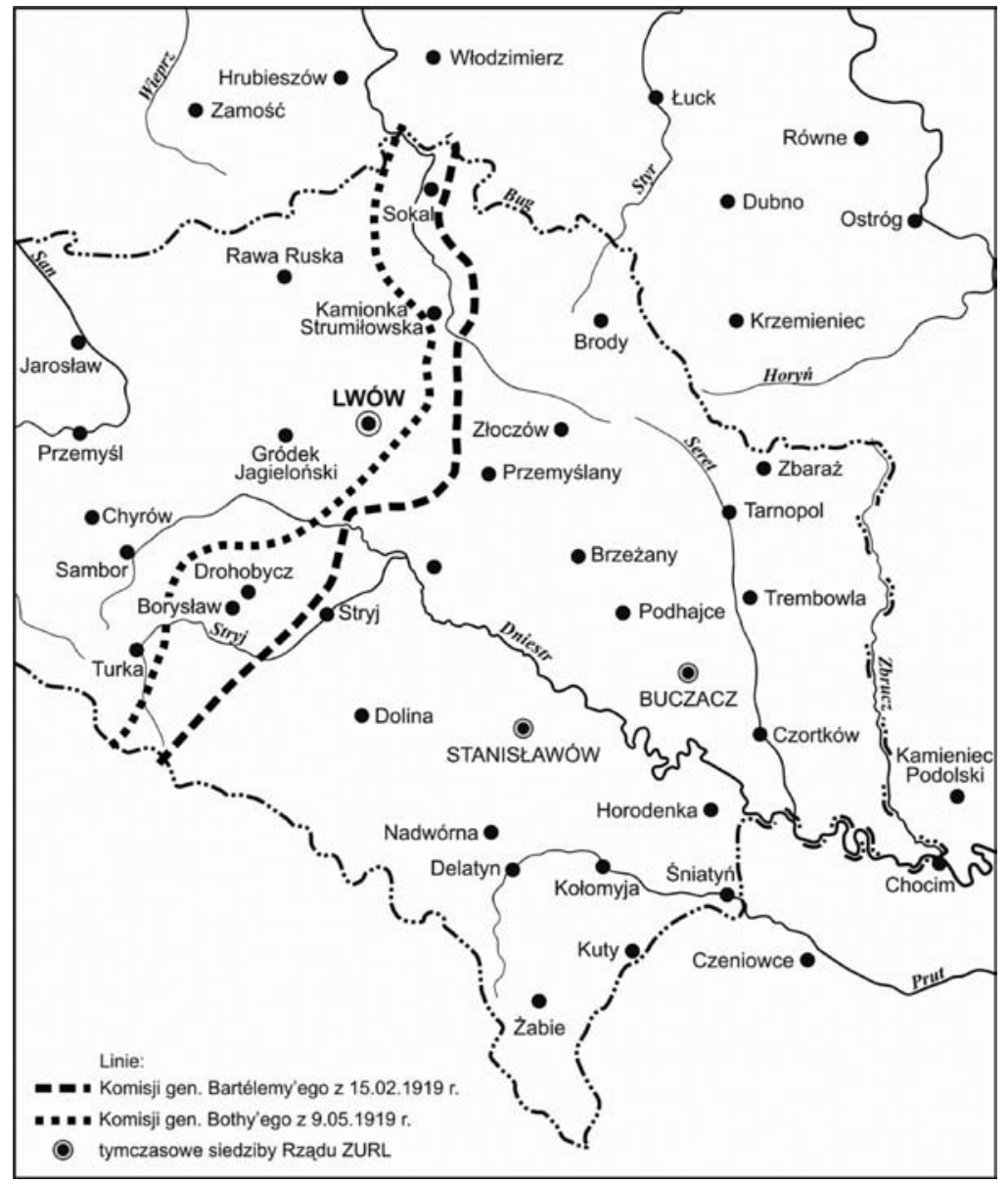

Opracowanie własne na podstawie: P. P. Żurawski vel Grajewski, Sprawa ukraińska na konferencji pokojowej w Paryżu w 1919 r., s. 118.

13 Złożoną problematykę związaną z rozgraniczeniem Galicji na dwie części przedstawiono w sposób szczegółowy w dwóch wartościowych opracowaniach: H. Batowski, Linia Curzona a była Galicja Wschodnia, w: H. Batowski, Z polityki międzynarodowej XX wieku: wybór studiów z lat 1930-1975, s. 186-193; L. Mroczka, Spór o Galicję Wschodniq 1914-1923, Kraków 1998. 
Rozwój wydarzeń we wschodniej Galicji był stale monitorowany przez Radę Najwyższą. W związku z tym Komisji do Spraw Polskich powierzono przedstawienie odpowiednich propozycji terytorialnych. Zostało to zrealizowane i 17 czerwca $1919 \mathrm{r}$. Komisja przygotowała trzy warianty rozwiązania gwarantującego wyjście z patowej sytuacji. Pierwszy z nich to ustanowienie mandatu nad wschodnią Galicją, który sprawowałaby Liga Narodów lub jedno z wielkich mocarstw. Drugi wariant to wcielenie do Polski przy zapewnieniu statusu autonomicznego. Trzeci zaś polegał na utworzeniu władzy tymczasowej i zorganizowaniu plebiscytu, który miałby moc wiążącą obie strony konfliktu. Przy każdym z tych wariantów miało być przeprowadzone rozgraniczenie między wschodnią a zachodnią Galicją. Wyznaczono przy tym dwie linie graniczne, pozostawiając ostateczną decyzję Radzie Najwyższej. Przy linii „A” zagłębie naftowe oraz Lwów pozostawały po wschodniej stronie. Ta propozycja była zbliżona do późniejszej linii Curzona. W wypadku przyjęcia linii „B” Lwów oraz zagłębie naftowe były włączone do tzw. właściwej Polski (ryc. 2). Opinie Rady Najwyższej były rozbieżne. Amerykańscy, francuscy i włoscy członkowie komisji optowali za linią „B”, Lloyd Georg zaś jako przewodniczący delegacji brytyjskiej skłaniał się do linii „A”.

Ryc. 2. Rozgraniczenie Galicji według linii Curzona (wariant „ $A^{\prime \prime} i_{\text {„” }} B^{\prime \prime}$ )

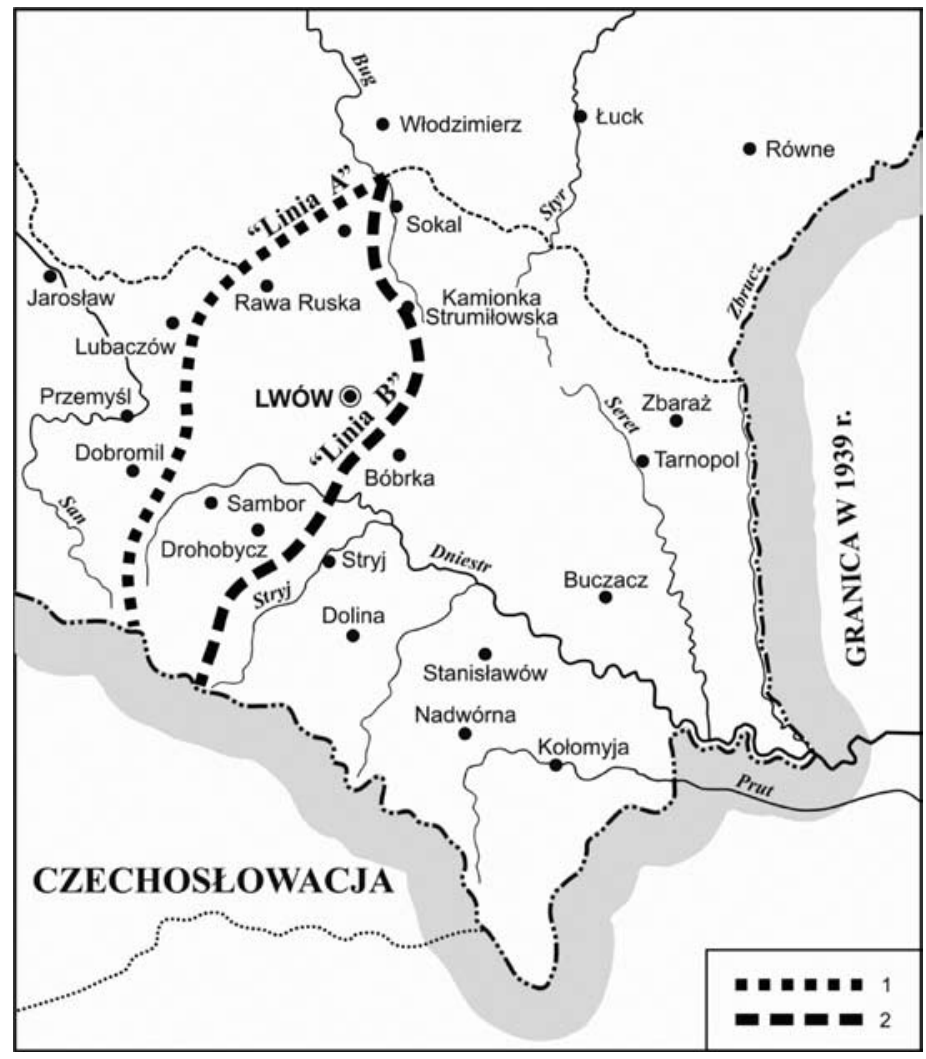

1 - „Linia Curzona A",

2 - „Linia Curzona B"

Opracowanie własne na podstawie: L. Kirkien, Russia, Poland and Curzon Line, Edynburgh 1944, s. 64. 
W rezultacie debaty ministrowie spraw zagranicznych państw zasiadających w Radzie Najwyższej podjęli 18 i 25 czerwca decyzję upoważniającą Polskę do wprowadzenia tymczasowej administracji na terenie całej wschodniej Galicji z zaleceniem przeprowadzenia plebiscytu i zagwarantowania w przyszłości autonomii.

Rozjemcze decyzje aliantów zachodnich szybko straciły aktualność, gdyż w lipcu 1919 r. wojska polskie zajęły całą Galicję aż po rzekę Zbrucz. W Paryżu zostało to przyjęte z wyraźną dezaprobatą. Strona brytyjska, w tym Lloyd George, zarzuciła rządowi polskiemu uprawianie polityki faktów dokonanych siłą militarną wbrew zaleceniom sprzymierzonych ${ }^{14}$. W późniejszym czasie stanowisko mocarstw zachodnich wobec polskiej granicy wschodniej zaczęło ulegać pewnej zmianie. Wiązało się to z rolą Polski jako przeciwnika bolszewickiej Rosji. Niemniej Komisja Cambona nadal nie przewidywała włączenia wschodniej Galicji do Polski na zasadach bezwarunkowej inkorporacji. Na podstawie decyzji z 21 listopada 1919 r. Polsce przekazano jedynie mandat ograniczony do 25 lat, przy jednoczesnym zobowiązaniu nadania autonomii terytorialnej. W rezultacie sprzeciwu rządu polskiego 22 grudnia 1919 r. nastąpiło zawieszenie tej decyzji i powrót do dalszych negocjacji.

Problem polskiej granicy wschodniej na obszarze byłego Cesarstwa Rosyjskiego nie był prawnie unormowany, gdyż do samego zakończenia obrad Kongresu Wersalskiego, czyli do 7 maja 1919 r., sprzymierzeńcy nie podjęli wiążącej decyzji. Uważano, że kwestia ta wymaga akceptacji nowego rządu rosyjskiego, który powstanie po pokonaniu bolszewików. Dlatego też w ostatecznym werdykcie pokojowym do tej kwestii jednoznacznie się nie odniesiono. Dla władz polskich ten brak rozstrzygnięcia był korzystny, gdyż dawał nadzieję na odzyskanie części ziem wschodnich I Rzeczypospolitej. Wymagało to jednak pokonania bolszewickiej Rosji i zmuszenie jej do równoprawnych rokowań pokojowych.

Wojska polskie w ciągu całego roku 1919 stopniowo przesuwały się na wschód. Między marcem a wrześniem opanowały Wilno, Baranowicze, Równe, Mińsk i dotarły do Berezyny, zajmując Borysów i Bobrujsk. Na froncie południowym po przekroczeniu Zbruczu jesienią 1919 r. opanowano Kamieniec Podolski (ryc. 3).

14 David Lloyd George (1863-1945), członek Partii Liberalnej, wieloletni członek Izby Gmin. Pełnił liczne funkcje ministerialne. Premier Wielkiej Brytanii od 1916 do 1922 r. Jeden z najważniejszych uczestników Konferencji Wersalskiej i przewodniczący delegacji brytyjskiej. Przeciwnik znaczniejszego uszczuplenia terytorium niemieckiego i retorsji antyniemieckich. Obawiał się nadmiernego wzmocnienia Francji. Odnosił się krytycznie do postulatu delegacji polskiej i zredukował jej roszczenia terytorialne. Był zwolennikiem ustalenia polskiej granicy wschodniej według kryteriów etnicznych i jego zalecenia były ściśle realizowane przez Lorda Curzona. W okresie międzywojennym utracił wpływy i znaczenie polityczne. 
Ryc. 3. Wyniki działań zbrojnych Wojska Polskiego. Obszary opanowane w okresie: koniec 1918 r. początek $1920 \mathrm{r}$.

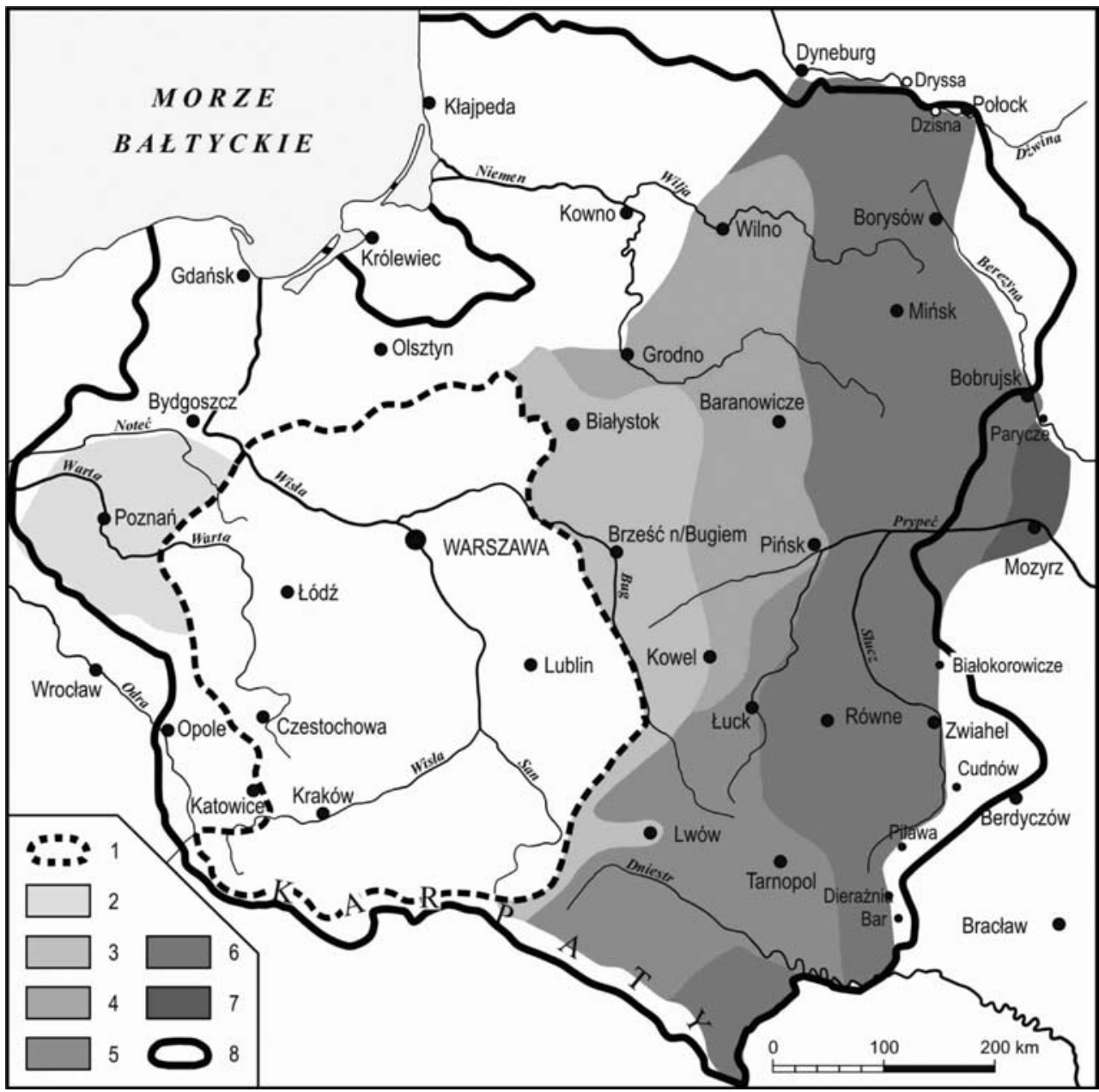

1 - listopad 1918, 2 - styczeń 1919, 3 - luty 1919, 4 - maj 1919, 5 - lipiec 1919, 6 - sierpień-grudzień 1919, 7 - marzec - 1920, 8 - linia Dmowskiego.

Opracowanie własne na podstawie: Dokumenty i materiały do historii stosunków polsko-radzieckich. T. II, s. 892 (załącznik).

Sukcesy militarne Polski nie były przyjmowane przez państwa Ententy z zadowoleniem, ale protesty były tonowane i formułowane w sposób niejednoznaczny. Nie wiedziano, kto zwycięży w wojnie domowej w Rosji. Sprzyjano „białym” generałom i w wypadku ich zwycięstwa zdawano sobie sprawę, że wyrażą oni zgodę jedynie na utratę Królestwa Polskiego. Z drugiej strony, traktowano Polskę jako „kordon sanitarny” 
oddzielający bolszewicką Rosję od pokonanych i upokorzonych Niemiec. Z tego powodu Polska uzyskiwała poważne wsparcie militarne i oczekiwano, że sytuacja w najbliższym czasie ostatecznie się wyklaruje.

Rada Najwyższa Sprzymierzonych na podstawie projektu opracowanego przez Komisję do Spraw Polskich 8 grudnia 1919 r. wyznaczyła linię demarkacyjną, opierając się o kryteria etniczne i historyczne. Była ona zbliżona do granicy caratu rosyjskiego z 1795 r. ustalonej po III rozbiorze Rzeczypospolitej ${ }^{15}$.

Rozgraniczenie to rozpoczynało się na północy przy ujściu Czarnej Hańczy do Kanału Augustowskiego i wzdłuż niego dochodziło do Niemna. Następnie szło nurtem tej rzeki bezpośrednio przy Grodnie, pozostawiając po stronie polskiej stację kolejową Łosośne, w dalszym ciągu swego przebiegu odchodziło od Niemna, idąc w pobliżu Jałówki w kierunku południowym, dochodziło do Bugu w rejonie Niemirowa, pozostawiając po stronie zachodniej Krynki, a po wschodniej Białowieżę z prawie całą Puszczą Białowieską, Wysokie Litewskie oraz Wołczyn. Następnie przebiegało już nurtem Bugu, pozostawiając Brześć po stronie wschodniej. Linią Bugu dochodziło do rejonu Hrubieszowa i Sokala i w tym miejscu definitywnie się kończyło. Granica nie rozgraniczała położonej bardziej na południe Galicji. To rozgraniczenie było zgodne z granicą, która dopiero później od nazwiska ministra spraw zagranicznych Lorda Curzona przyjęła złowrogą nazwę „linii Curzona” ${ }^{\prime 16}$.

Wyznaczona wówczas linia demarkacyjna nie miała charakteru ostatecznego. Mało tego, stwierdzono jednocześnie, że Polska ma prawo do terytoriów położonych na wschód od tego rozgraniczenia. Oznaczało to jedynie, że Polska może organizować stałą administrację na terenach położonych na zachód od tej zaproponowanej linii

${ }^{15}$ W deklaracji Rady Najwyższej konferencji pokojowej podpisanej przez prezydenta Rady Najwyższej Mocarstw Sprzymierzonych i Stowarzyszonych G. Clemenceau dnia 8 grudnia 1919 r. linia ta została bardzo dokładnie wytyczona według kolejnych punktów topograficznych, a mianowicie: „Linia ta biegnie: Poczynając od byłej granicy austriackiej wzdłuż Bugu, aż do punktu skrzyżowania się granicy administracyjnej powiatu brzeskiego i bielskiego, następnie na północ mniej więcej w odległości $9 \mathrm{~km}$ na północny wschód od Mielnika, później na wschód przecinając linię kolejową Brześć Litewski-Bielsk koło Kleszczeli, w dwu kilometrach na zachód od Skupowa, następnie $4 \mathrm{~km}$ na północ od Jałówki, następnie wzdłuż Świsłoczy, zbaczając na zachód od Baranowa przez miejscowość Kiełbasin pod Grodnem, następnie wzdłuż Łosośny, dopływu Niemna aż do Studzianki, Marychy, przez Zelwę, Berżniki, Zegary ..." (K. W. Kumaniecki, op. cit., s. 177).

${ }^{16}$ George Nathaniel Curzon (1859-1925), znany w literaturze jako Lord Curzon. Polityk Partii Konserwatywnej. Pod koniec XIX w. pełnił funkcję tzw. wicekróla Indii. W styczniu 1919 r. objął stanowisko ministra spraw zagranicznych Wielkiej Brytanii, które pełnił do 1922 r. Brał udział w Konferencji Wersalskiej, gdzie sprzyjał stronie niemieckiej i skutecznie blokował graniczne postulaty polskie. Na polecenie Lloyda George’a 8 grudnia 1919 r. zaproponował linię demarkacyjną mającą być tymczasową wschodnią granicą Polski. Nawiązywała ona do zachodniej granicy Rosji ustalonej po III rozbiorze. Dochodziła do granicy austriackiej w pobliżu Kryłowa. Granica ta przyjęła nazwę „linii Curzona”, chociaż rola Curzona w jej wyznaczeniu był drugorzędna, a sama nazwa została przyjęta w późniejszym czasie. Działalność polityczna Curzona jest obiektem zainteresowania historyków. Do ciekawych opracowań na jego temat należy: J. G. Parker, Lord Curzon 1859-1925: a bibliography, New York 1991 oraz D. Gilmour, Curzon - imperial statesman 1895-1925, Londyn 2003. 
granicznej, roszczenia zaś państwa polskiego do ziem leżących bardziej na wschód są w pełni uzasadnione i będą respektowane. Postanowienia te nie miały więc charakteru obligatoryjnego. Dopiero późniejsze nadinterpretacje dowodziły o ostatecznym werdykcie ustalającym granicę między Polską a bolszewicką Rosją. W każdym razie ustalenia podjęte 8 grudnia 1919 r. przyniosły niezmiernie istotne konsekwencje, gdyż do nich później wielokrotnie nawiązywano i sugerowano, że są zgodne z normami prawa międzynarodowego ${ }^{17}$.

W ówczesnej sytuacji politycznej i militarnej nie miały one dużego znaczenia, gdyż front polsko-bolszewicki przebiegał o $300 \mathrm{~km}$ dalej na wschód. Obawiając się powodzenia oręża polskiego oraz wobec trudnej sytuacji wewnętrznej, rząd bolszewicki 23 grudnia 1919 r. zwrócił się do Polski z propozycją zawarcia pokoju. Zostało ono ponowione 28 stycznia 1920 r. oświadczeniem podpisanym przez Lenina, Cziczerina i Trockiego. Proponowano ustalenie linii rozejmowej zbliżonej geograficznie do linii Dmowskiego. Oferta ta różniła się od propozycji polskiego polityka jedynie w szczegółach. Nie przyznawała Polsce miasta Połocka i obszarów położonych na północ od Dźwiny, natomiast ustępowała Polsce rejon w pobliżu Baru na Ukrainie. Dawano przy tym do zrozumienia, że wspomniana linia rozejmowa może stać się granicą między obu państwami. Należy przypuszczać, że ta atrakcyjna propozycja miała charakter taktyczny i po demobilizacji armii polskiej pod dowolnym pretekstem nastąpiłoby jej zakwestionowanie w imię konieczności wywołania głoszonej rewolucji światowej lub wsparcia proletariatu polskiego lub niemieckiego. Po długiej zwłoce 6 kwietnia 1920 r. nota sowiecka została ostatecznie przez Polskę odrzucona ${ }^{18}$.

Po sukcesach militarnych wojska polskiego rozpoczęly się niepowodzenia. Po utracie Kijowa nastąpiła klęska na Białorusi i Ukrainie. Armia Czerwona rozpoczęła zwycięski marsz na zachód. Pojawiło się prawdopodobieństwo ewentualnego upadku państwa polskiego. W tak groźnej sytuacji rządy Ententy podjęły inicjatywę pokojową zmierzającą do zawieszenia broni i zawarcia pokoju.

W trakcie obrad międzynarodowej konferencji sojuszniczej w Spa 10 lipca 1920 r. Brytyjczycy wysunęli projekt wycofania wojsk polskich na linię demarkacyjną określoną przebiegiem południkowym dwóch rzek: Niemna i Bugu, a sprawę przynależności wschodniej Galicji rząd polski miał przekazać do rozstrzygnięcia mocarstwom Ententy, z tym że na obszarze Galicji linia demarkacyjna miała być zgodna z przebiegiem frontu

${ }^{17}$ W Instytucie Hoovera znajduje się oryginalna dokumentacja związana z propozycją brytyjską i jej konsekwencjami w wyznaczaniu granicy wschodniej Polski według linii Curzona. Są tam m.in. opracowania wykonane przez Ministerstwo Spraw Kongresowych utworzone przy Rządzie Polskim w Londynie: The Legend of the Curzon Line, Poland: Ministerstwo Prac Kongresowych Collection, Box No 1, Hoover Institution Archives In Stanford; The So-Called Curzon Line, Ministerstwo Prac Kongresowych Collection, Box No 1, Hoover Institution Archives In Stanford.

${ }_{18}$ Obszerny zestaw dokumentów dotyczących stosunków polsko-sowieckich związanych z wojną, jak i pertraktacjami pokojowymi został opublikowany w latach 60. XX w.: Dokumenty i materiały do historii stosunków polsko-radzieckich. T. II, listopad 1918 - kwiecień 1920, red. N. Gąsiorowska-Grabowska, I. A. Chrienow, Warszawa 1961; Dokumenty i materiały do historii stosunków polsko-radzieckich. T. III, kwiecień 1920 - marzec 1921, red. N. Gąsiorowska-Grabowska, I. A. Chrienow, Warszawa 1964. 
polsko-bolszewickiego. W tym czasie front dopiero zbliżał się do Zbrucza. Obszar Zagłębia Naftowego oraz Lwów był jeszcze niezagrożony. Zakładano, że Galicja będzie podzielona linią demarkacyjną wytyczoną na wschód od Lwowa. Projektodawcą tej propozycji był Lloyd George, który wyraźnie nawiązywał do deklaracji sprzymierzonych z 8 grudnia 1919 r. Jego intencją było wyznaczenie linii demarkacyjnej satysfakcjonującej strony konfliktu, co dawałoby gwarancję zakończenia wojny. Podjęto decyzję, że propozycja mocarstw zachodnich zostanie natychmiast przesłana do Komisarza Spraw Zagranicznych bolszewickiej Rosji Gieorgija Cziczerina.

Bezpośrednio po tych ustaleniach w nocy z 10 na 11 lipca 1920 r. z Ministerstwa Spraw Zagranicznych Wielkiej Brytanii został wysłany telegram sygnowany przez ministra spraw zagranicznych Wielkiej Brytanii Curzona do Komisariatu Spraw Zagranicznych, a osobiście do rąk Cziczerina. To służbowe polecenie według najbardziej wiarygodnej wersji było realizowane przez Lewisa Bernsteina-Niemirowskiego (używającego nazwiska Namier ${ }^{19}$ ). Był on osobą wpływową, blisko związaną zarówno z Lloydem Georgem, jak i z Lordem Curzonem. Miał on własną ocenę sytuacji w Galicji i sprzyjał stronie ukraińskiej. W treści telegramu nastąpiła zmiana. Propozycja przebiegu linii demarkacyjnej na obszarze Galicji została przesunięta w ten sposób, że Lwów z Zagłębiem Naftowym znalazł się po wschodniej stronie proponowanego rozgraniczenia i w tej postaci informacja dotarła do Komisariatu Spraw Zagranicznych bolszewickiej Rosji (Cziczerina). Motywy postępowania Namiera nie są w pełni wyjaśnione. Były one zgodne z Lloyd’a George’a i Lorda Curzona poglądami. Dlatego też była to weryfikacja zamierzona, a nie przypadkowa lub wynikająca z błędu technicznego. Strona brytyjska nie próbowała jej sprostować i nie podchodziła do niej w sposób pryncypialny.

Rząd bolszewicki otrzymał więc konkretną propozycję rozgraniczenia rozjemczego. Była ona określona w sposób precyzyjny i przebiegała od Kanału Augustowskiego po Karpaty na południu.

Władze bolszewickiej Rosji odrzuciły wówczas propozycje linii demarkacyjnej ustalonej przez mocarstwa Ententy. Formalnie uczyniły to 17 lipca 1920 r. Rząd bolszewicki, w tym również Lenin, liczył na szybkie pokonanie Polski i dotarcie do granicy niemieckiej. Zakładano, że niebawem nastąpi rewolucja światowa, która zmieni porządek europejski. Dlatego też pośrednictwo państw Ententy było zbyteczne. Dla zakamuflowania swoich celów dyplomacja bolszewicka głosiła retorycznie potrzebę bezpośrednich rokowań polsko-bolszewickich. W praktyce zaś zmierzała

${ }^{19}$ Lewis Bernstein-Namier (1888-1960), urodzony w Królestwie Polskim w rodzinie żydowskiej jako Ludwik Niemirowski. Studiował we Lwowie i Lozannie. W 1906 r. wyemigrował do Wielkiej Brytanii. Zajmował wysokie stanowiska w brytyjskim ministerstwie spraw zagranicznych (1918-1920). Na konferencji w Wersalu rząd brytyjski powierzył mu funkcję eksperta do spraw polskich. Przeciwnik polityczny R. Dmowskiego. Uważa się, że był celowym sprawcą przeinaczenia treści telegramu wystosowanego z Ministerstwa Spraw Zagranicznych Wielkiej Brytanii do Komisariatu Spraw Zagranicznych bolszewickiej Rosji. Nastąpiło w nim przesunięcie południowego odcinka tzw. „linii Curzona” przechodzącego przez Galicję w przybliżeniu o $50 \mathrm{~km}$ na zachód z wariantu „B” na wariant „A”. Pozbawiło to Polskę Lwowa i Zagłębia Naftowego. Po odejściu ze służby dyplomatycznej zajmował stanowisko profesora historii na Uniwersytecie w Manchester. 
do zniewolenia Polski i stworzenia kolejnej republiki sowieckiej. Polska delegacja na konferencji w Spa 10 lipca 1920 r. zgodziła się na zawarcie rozejmu i wycofanie wojsk na linię demarkacyjną zaproponowaną przez Lloyda George’a, czyli na linię Curzona. Ze względu na fakt, że strona bolszewicka nie wyraziła na to zgody, nie miało to już wówczas żadnego znaczenia politycznego i militarnego.

Następna konferencja sprzymierzonych odbyła się w sierpniu 1920 r. w Sévres. Działo się to w sytuacji, gdy wojska bolszewickie dotarły do Wisły i los Polski wydawał się przesądzony. Mocarstwa zachodnie podjęły próbę ratowania odrębności wschodniej Galicji poprzez obietnice utworzenia suwerennego podmiotu politycznego. Było to zignorowane nie tylko przez bolszewicką Rosję, lecz także Polskę.

Zwycięstwo w Bitwie Warszawskiej, a następnie pokonanie bolszewików nad Niemnem i w pobliżu Komarowa na Lubelszczyźnie zmieniło sytuację militarną i polityczną. Wojska polskie dotarły do Mińska oraz przekroczyły Zbrucz. Strona bolszewicka zdała sobie sprawę z nierealności pokonania Polski. Rozpoczęły się rokowania pokojowe, które zakończyły się ustaleniem na konferencji w Rydze 18 marca 1921 r. nowej wschodniej granicy Polski, która została ratyfikowana przez Sejm Rzeczypospolitej Polskiej 15 kwietnia $1921 \mathrm{r}$.

Granica polsko-sowiecka o długości 1412 km przebiegała od Dźwiny na północy, czyli od granicy polsko-łotewskiej, następnie kierowała się na wschód do Dryssy i dalej idąc południkowo w pobliżu miejscowości: Raków, Stołpce i Dawidgródek, gdzie przecinała Prypeć i dochodziła do Zbrucza. Przy połączeniu Zbrucza z Dniestrem docierała do granicy polsko-rumuńskiej. W granicach państwa znalazła się cała Galicja należąca do zaboru austriackiego, większa część Wołynia i Polesia, Wileńszczyzna oraz zachodnia część Mińszczyzny. Ustalona linia graniczna pokrywała się w przybliżeniu z granicą drugiego rozbioru Polski (1792).

Uzgodniona granica $\mathrm{w}$ traktacie ryskim nie była kwestionowana przez władze sowieckie przez cały okres międzywojenny. Dyskutowana w latach 1919-1920 linia Curzona uległa w zasadzie zapomnieniu. Nie była ona przypominana i traktowano ją jako mało ważny i zdezaktualizowany epizod rokowań pokojowych.

\section{Ustalenie linii Curzona jako wschodniej granicy Polski w czasie II wojny światowej}

Armia Czerwona przekroczyła granicę polsko-sowiecką 17 września 1939 r. Agresja na Polskę została poprzedzona paktem o nieagresji między Rzeszą Niemiecką a ZSRR zawartym 23 sierpnia $1939 \mathrm{r}$. Na podstawie tego porozumienia nastąpił podział terytorium państwa polskiego. Ustalono rozgraniczenie wzdłuż linii czterech rzek: Sanu, Wisły, Narwi i Pissy. Zostało ono zmienione w rezultacie kolejnej umowy zawartej między obu agresorami w dniu 28 września 1939 r. Ustalono wówczas nową linię demarkacyjną. Nastąpiło przesunięcie rozgraniczenia sowiecko-niemieckiego z linii Wisły na linię środkowego Bugu ${ }^{20}$. Lubelszczyzna w zamian za Litwę weszła do oku-

\footnotetext{
${ }^{20}$ Przesunięcia polskiej granicy wschodniej w okresie II wojny światowej zostały w obszerny sposób zreferowane w książce autora: P. Eberhardt, Polska granica wschodnia 1939-1945, Warszawa 1992.
} 
pacyjnej strefy niemieckiej. Granica między obu strefami rozpoczynała się w górnym biegu Sanu. Następnie, idąc nurtem tej rzeki, dochodziła do Sieniawy, miejscowości położonej w pobliżu Jarosławia. W rejonie tym granica odbiegała od Sanu i w linii prostej dochodziła do Krystynopola, położonego po zachodniej stronie Bugu. Po czym na długim odcinku wytyczono ją nurtem rzeki Bug aż do miejscowości Nur. W tym miejscu odchodziła od rzeki i wyznaczona była już wzdłuż linii prostej i dochodziła do Narwi w rejonie Ostrołęki. Na dalszym odcinku granica szła wzdłuż Narwi, następnie docierała do Pissy i, idąc jej nurtem, dochodziła do granicy Prus Wschodnich. Na skutek zabiegów Ribbentropa ZSRR odstąpił Niemcom Suwalszczyznę. Po podpisaniu niemiecko-sowieckiego traktatu „o granicach i przyjaźni” obie strony uznały tę granicę za ostateczną. W późniejszym czasie przyjęła ona nazwę „linii demarkacyjnej Ribbentrop-Mołotow" i trwała od 28 września 1939 r. do 22 czerwca 1941 r.

Wytyczona granica nie była zgodna z tzw. linią Curzona. W późniejszym czasie władze sowieckie starały się ją utożsamiać $\mathrm{z}$ tą linią, ale nie było to zgodne z prawdą. Jedynie na odcinku środkowym wzdłuż Bugu obie linie były ze sobą zbieżne. Na południu linia demarkacyjna była wyznaczona wzdłuż górnego Sanu i była przesunięta na zachód w stosunku do linii Curzona, zarówno w rejonie Birczy, jak i Lubaczowa. Obie linie demarkacyjne znacznie różniły się na odcinku północnym, gdyż województwo białostockie (bez powiatu Grodno i Wołkowysk) było po zachodniej stronie linii Curzona, podczas gdy w rozgraniczeniu sowiecko-niemieckim ustalonym zarówno 23 sierpnia 1939 r., jak i 28 września 1939 r. cała Białostocczyzna oraz trzy powiaty woj. warszawskiego zostały włączone do Białoruskiej SRR ${ }^{21}$.

Wojna sowiecko-niemiecka rozpoczęła się 22 czerwca $1941 \mathrm{r}$. Linia demarkacyjna ustalona 28 września 1939 r. została przekroczona przez wojska niemieckie na całej swej długości i faktycznie przestała istnieć. Pakty sowiecko-niemieckie straciły rację bytu, a problem przyszłości Polski i jej granic wschodnich stawał się sprawą otwartą. Cały obszar przedwojennej Polski został okupowany przez hitlerowskie Niemcy. Zniknął kordon sowiecko-niemiecki, a administracja niemiecka wprowadziła nowe rozgraniczenia administracyjne. Galicja Wschodnia (tzw. Małopolska Wschodnia) została włączona do Generalnego Gubernatorstwa jako odrębny dystrykt. Cały Wołyń oraz południowe Polesie weszły w skład tzw. Reichskommisariat Ukraine. Województwo białostockie zostało wcielone do Prus Wschodnich. Ziemie północno-wschodniej Polski weszły do tzw. Reichskommisariat Ostland.

Napad Hitlera na ZSRR był wydarzeniem korzystnym dla Wielkiej Brytanii, która uzyskiwała silnego sojusznika. Układ o wspólnych działaniach rządów ZSRR i Wielkiej Brytanii przeciwko Niemcom został podpisany 12 lipca 1941 r. w Moskwie przez Mołotowa i Crippsa w obecności Stalina. Równolegle rozpoczęły się rozmowy między premierem rządu polskiego, generałem Sikorskim, a ambasadorem sowieckim w Londynie - Majskim, które ujawniły poważne rozbieżności w sprawie

${ }^{21}$ Stosunki sowiecko-niemieckie w okresie 1939-1941 oraz kwestie rozgraniczenia stref wpływów obu agresorów omawia: A. Bregman, Najlepszy sojusznik Hitlera, Londyn 1974. 
granicy polsko-sowieckiej. Strona polska domagała się pełnego respektowania granicy polsko-sowieckiej ustalonej w traktacie ryskim, natomiast Majski stał na stanowisku niepowoływania się na ten traktat i ustalenia nowych granic na podstawie kryteriów etnograficznych, gdyż rząd sowiecki nie może uznać granic z 1939 r.

Ze względu na trudności porozumienia do pertraktacji włączył się osobiście Churchill oraz jego minister spraw zagranicznych Anthony Eden. Na skutek silnej presji na rząd polski nowy układ polsko-sowiecki został ostatecznie podpisany 30 lipca 1941 r. przez Sikorskiego i Majskiego. Oba państwa nawiązały stosunki dyplomatyczne, problem zaś przywrócenia granic przedwojennych został sformułowany w sposób niejednoznaczny, umożliwiający dowolną jego interpretację. Było to ujęte w sposób następujący: „Rząd ZSRR uznaje, że traktaty sowiecko-niemieckie z 1939 r. dotyczące zmian terytorialnych w Polsce utraciły swoją moc". Sprawa granic była przez obie strony odmiennie komentowana i zawieszona do późniejszych rokowań. Rząd polski twierdził, że konsekwencją wypowiedzenia traktatów z Niemcami musi być powrót do granic ustalonych w Rydze. Anulowanie zaś paktu z Niemcami nie musiało się wiązać dla ZSRR z przywróceniem granic przedwojennych. Ta nieprecyzyjność układu spowodowała kryzys w polskim rządzie w Londynie. Nie miało to jednak dużego znaczenia politycznego. Natomiast moskiewska „Izwiestia” z 3 sierpnia 1941 r. odnotowała, że sprawa granic Polski na wschodzie zostaje otwarta, że traktat ryski nie jest wieczny oraz że ziemie wschodniej Polski to obszary ukraińskie i białoruskie, a nie polskie ${ }^{22}$.

Problematyka granicy polsko-sowieckiej była omawiana w trakcie pobytu Sikorskiego w grudniu 1941 r. w Moskwie. W trakcie rozmów z Sikorskim Stalin zaproponował rozpatrzenie tej kwestii w rozmowach dwustronnych. Sikorski jednak uważał, że nie można kwestionować granicy ryskiej i uchylił się od tej propozycji. W ciągu drugiego półrocza $1941 \mathrm{r}$. w sytuacji porażek armii sowieckiej na froncie ze strony Moskwy nie padały konkretne sugestie graniczne. Nie przypominano również historycznej propozycji Lorda Curzona z 1919 r. Po zwycięstwie nad wojskami niemieckimi pod Moskwą postawa sowiecka stawała się coraz bardziej nieprzejednana. W odpowiedzi na notę rządu polskiego rząd sowiecki stwierdzał, że „przyłączenie wskazanych obszarów (czyli zachodniej Ukrainy i Białorusi) do ZSRR było rezultatem swobodnie wyrażonej woli ludności"23.

Natomiast strona brytyjska coraz przychylniej przyjmowała argumentację sowiecką. Ujawniło się to w rozmowie Sikorskiego z Crippsem 26 stycznia 1942 r. Ambasador brytyjski w Moskwie stwierdził: „Co się tyczy granicy polsko-rosyjskiej Rosja przedłoży raczej daleko idące żądania. W nieoficjalnych kołach rosyjskich wymieniono nawet linię Curzona”. Było to pierwsze przypomnienie linii Curzona jako wschodniej granicy Polski przez przedstawiciela Wielkiej Brytanii. Stanowisko Wielkiej Brytanii

22 W. Pobóg-Malinowski, Najnowsza historia polityczna Polski: okres 1939-1945, t. I, Gdańsk 1991, s. 198.

${ }^{23}$ W. Pobóg-Malinowski, op. cit., s. 220. 
wobec sowieckich postulatów terytorialnych zaczęło ulegać zasadniczej reorientacji ${ }^{24}$. Przemiana ta wynikała z obawy Churchilla przed możliwością zawarcia separatystycznego pokoju między Niemcami a ZSRR. Była ona całkowicie nierealistyczna, lecz wpływała na prowadzenie polityki ustępstw.

W ciągu całego 1942 r. ZSRR niejednokrotnie dawał do zrozumienia, że swoje granice z czerwca 1941 r. (czyli ustalone w rezultacie paktu Ribbentrop-Mołotow) uważa za legalnie obowiązujące nie na zasadzie wspomnianego porozumienia, ale na podstawie plebiscytu ludności zachodniej Białorusi i Ukrainy. Pod koniec 1942 r. rząd polski ponownie na porządku dnia postawił problem granicy polsko-sowieckiej. Stanowisko sowieckie było coraz bardziej nieprzejednane i wrogie. Polskie oświadczenia zaczęły odgrywać coraz mniejszą rolę ze względu na postawę sojuszników zachodnich. Odpowiedzi sowieckie były coraz mniej kompromisowe. Niemniej strona sowiecka przestała przypominać konieczność przywrócenia granicy z czerwca 1941 r., a zaczęła głosić potrzebę wytyczenia granic na podstawie historycznej propozycji Lorda Curzona. Można to odczytać w oświadczeniu sowieckiej agencji TASS z 1 marca 1943 r. w związku z uchwałą rządu polskiego z 25 lutego $1943 \mathrm{r}$. W nocie tej stwierdzono: „Sowieckie koła kierownicze uważają, że negowanie prawa narodu ukraińskiego i białoruskiego do zjednoczenia się ze swymi braćmi świadczy o istnieniu tendencji imperialistycznych, a powoływanie się rządu polskiego na Wielką Kartę Atlantycką nie ma żadnych podstaw. Wielka Karta Atlantycka nie daje nikomu prawa czynić zamachu na prawa narodowe Ukraińców i Białorusinów, ale przeciwnie, wychodzi ona z założeń uznania narodowych praw narodów, w tym narodu ukraińskiego. Nawet znany minister brytyjski Lord Curzon, pomimo swego nieprzejednanego stosunku do ZSRR, zrozumiał, że Polska nie może pretendować do ziem ukraińskich i białoruskich, a polskie koła rządzące nie chcą dotychczas okazać zrozumienia w tej sprawie" 25 . W polskiej odpowiedzi na tę notę stwierdzono, że linia Curzona była projektowana jedynie w czasie działań wojennych w latach 1919-1920 jako linia rozejmowa, a nie graniczna. Tego typu polemika nie miała już dużego znaczenia. Podobnie jak interwencja rządu polskiego u mocarstw zachodnich. Dla Wielkiej Brytanii i Stanów Zjednoczonych była to sprawa drugorzędna, a stosunki ich z ZSRR były na tyle ważne, że nie chcieli prowadzić w tej kwestii niepotrzebnej polemiki. Zresztą argumenty sowieckie były dla nich bardziej zrozumiałe i uważali, że ZSRR, ponosząc tak wielkie ofiary na wojnie, ma prawo do wytyczenia swojej granicy zachodniej zgodnie ze swoimi potrzebami militarnymi ${ }^{26}$.

${ }^{24}$ J. Karski, Wielkie mocarstwa wobec Polski 1919-1945: od Wersalu do Jałty, Lublin 1998, s. 343344.

${ }^{25}$ Sprawa polska $w$ czasie drugiej wojny światowej na arenie międzynarodowej. Zbiór dokumentów, red. nauk. S. Stanisławska, Warszawa 1965, s. 338.

${ }^{26}$ Ponawiane stale przez rząd polski apele do Churchilla i Roosevelta w sprawie wsparcia polskiego stanowiska wobec granicy polsko-sowieckiej nie przynosiły oczekiwanych skutków. Churchill był w tej kwestii w miarę prostolinijny i nie składał obietnic bez pokrycia. Natomiast Roosevelt w rozmowach z polskimi politykami (Sikorskim, a później Mikołajczykiem) wprowadzał ich celowo w błąd, gdyż 
Stosunki dyplomatyczne między rządem polskim a ZSRR stawały się coraz bardziej napięte. Pretekstem ich oficjalnego zerwania była zbrodnia katyńska i zwrócenie się rządu polskiego do Międzynarodowego Czerwonego Krzyża. Postępująca izolacja polityczna Polski zmniejszała możliwości oddziaływania, które i tak były bardzo skromne. Zdając sobie sprawę z tych niekorzystnych uwarunkowań, Sikorski zaczął skłaniać się do ewentualnych ustępstw granicznych. Myślał o rezygnacji z Polesia, Wołynia i części Podola w zamian za rekompensaty terytorialne kosztem Niemiec. W związku z tym zamierzał udać się do Moskwy na bezpośrednie rozmowy ze Stalinem. Zanim jednak zdołał zrealizować planowaną wizytę, zginął tragicznie 4 lipca 1943 r. Nowym premierem rządu polskiego został Stanisław Mikołajczyk. W toku przygotowań do moskiewskiej konferencji ministrów spraw zagranicznych trzech głównych mocarstw strona brytyjska próbowała narzucić rządowi Mikołajczyka konieczność uznania linii Curzona jako granicy polsko-sowieckiej. Oferta ta została odrzucona i rząd polski nadal stał na stanowisku utrzymania granicy ryskiej.

O przyszłości Polski i układzie jej granic politycznych miało zadecydować spotkanie przywódców trzech wielkich mocarstw, czyli Stalina, Roosevelta i Churchilla. Odbyło się ono w dniach 28 listopada - 1 grudnia 1943 r. w Teheranie. Miało ono decydujące znaczenie dla polskiej granicy wschodniej, więc należy przedstawić przebieg pertraktacji w sposób możliwie wierny ${ }^{27}$. Początkowo stanowisko Stalina było nieustępliwe. Jedynym słusznym dla ZSRR rozstrzygnięciem jest granica demarkacyjna istniejąca między 1939 a 1941 r. Wypowiedź Stalina uzupełnił Mołotow, twierdząc, że granica, o której mówił Stalin jest linią Curzona. Brytyjscy uczestnicy obrad zakwestionowali pogląd Mołotowa. Rozłożyli na stole mapę, na której zaznaczone były różnice między linią Curzona pozostawiającą po stronie polskiej większą część woj. białostockiego a linią graniczną z 22 czerwca 1941 r. Po pewnym czasie Mołotow zorientował się, że nie udało mu się wprowadzić w błąd sojuszników zachodnich, Stalin zaś w końcu uznał, że obie linie graniczne nie są zbieżne.

$\mathrm{W}$ dalszym ciągu dyskusji podjęto rozważania nad przebiegiem południowego odcinka linii Curzona. Eden przypomniał, że w tej części, czyli w Galicji, linia Curzona nie została wyznaczona, a Lwów powinien zostać po stronie polskiej. Na to stwierdzenie Mołotow wysłał sekretarza po sowieckie mapy, a następnie odczytał pełny tekst noty Lorda Curzona skierowanej 11 lipca 1919 r. do rządu bolszewickiej Rosji. Dokument ten,

obiecywał pomoc dla polskich dezyderatów, a w gruncie rzeczy w pełni podzielał sowiecki punkt widzenia na problematykę graniczną. Stanowisko obu mocarstw zachodnich było więc w zasadzie zbieżne, a różniło się jedynie retoryką. Na początku 1943 r. nastąpiło uzgodnienie stanowiska brytyjsko-amerykańskiego w kwestii Europy Środkowej oraz polskiej granicy wschodniej. Do Waszyngtonu udał się minister spraw zagranicznych Wielkiej Brytanii A. Eden i przebywał tam do 12 do 30 marca 1943 r. Doszło wówczas do nieformalnego tajnego porozumienia między obu mocarstwami zachodnimi. Eden wyraził zgodę na włączenie do ZSRR Litwy, Łotwy i Estonii oraz przyznanie ZSRR baz w Finlandii i Rumunii i oddanie ZSRR wschodniej części Polski po linię Curzona (J. Karski, op. cit., s. 347).

27 Stenogramy rozmów między Stalinem, Rooseveltem i Churchillem zawarte są w opracowaniu: Teheran - Jałta - Poczdam. Dokumenty konferencji szefów rządów trzech wielkich mocarstw, tłum. W. Daszkiewicz, A. Rotfeld, Warszawa 1972. 
ustanawiając linię rozejmową, nie wskazywał jednoznacznie, który z dwóch wariantów "A" czy „B” - ma być obowiązujący. W związku z tym rozpoczął się spór interpretacyjny. Eden bronił interesów polskich, wskazując, że Lwów powinien należeć do Polski. W tym momencie Churchill zwrócił się do Edena i powiedział, że nie będzie łamał sobie serca z powodu Lwowa. Powtórzył następnie w obecności Mołotowa znane sformułowanie: „Nie mam zamiaru podnosić lamentu z powodu Lwowa”.

Na zakończenie obrad głos zabrał Churchill, który zaproponował wstępną wersję końcowej rezolucji o następującej treści: „Przyjęto w zasadzie, że ognisko państwa i narodu polskiego powinno znajdować się między tak zwaną linią Curzona a linią rzeki Odra z włączeniem w skład Polski Prus Wschodnich i prowincji opolskiej”. Na propozycję Churchilla odpowiedział Stalin, który zażądał północnej części Prus Wschodnich z Królewcem. Jeżeli ten postulat zostałby spełniony przez aliantów zachodnich, to strona sowiecka wyraziłaby zgodę na propozycję Churchilla. Wniosek ten został zaakceptowany przez Churchilla i Roosevelta. Osiągnięte porozumienie na konferencji w Teheranie miało zasadnicze znaczenie dla polskiej granicy wschodniej. Została ona w pełni uzgodniona przez trzy wielkie mocarstwa. Ostatecznie ustalono, że linia Curzona będzie wschodnią granicą Polski. Jednocześnie wyrażona została zgoda na aneksję północnych Prus Wschodnich przez ZSRR. Polska nie tylko traciła wschodni obszar kraju, lecz także na północy miała też graniczyć ze Związkiem Sowieckim. W sprawach granicy polsko-sowieckiej żądania ZSRR zostały zaspokojone. Jedynym ustępstwem było wycofanie się z linii demarkacyjnej z 1941 r. Mówiąc hasłowo o linii Curzona, nie poruszono w ostatecznej redakcji przynależności Lwowa, który mógł się znaleźć zarówno po wschodniej, jak zachodniej stronie granicy. Stalin bez wątpienia zakładał, że Lwów będzie sowiecki. Dawało to jednak w przyszłości możliwość ponownego rozpatrzenia przebiegu południowego odcinka linii Curzona.

Decyzje teherańskie nie zostały oficjalnie ujawnione i nie przekazano ich drogą urzędową do wiadomości rządu polskiego. Bezpośrednio po konferencji w Teheranie rząd Mikołajczyka był nieświadomy, że przebieg polskiej granicy wschodniej został już rozstrzygnięty i stanowisko trzech mocarstw w tej kwestii jest jednomyślne. Kilkumiesięczny okres po konferencji teherańskiej to stałe rozmowy między rządem polskim, reprezentowanym przez Mikołajczyka, a Churchillem, który próbował skłonić Polaków do akceptacji linii Curzona jako wschodniej granicy Polski ${ }^{28}$. Było to warunkiem porozumienia polsko-sowieckiego. Strona polska nie poddała się presji Churchilla. Jedynym

${ }^{28}$ Poglądy Churchilla w stosunku do kwestii niepodległości Polski i jej granic są przedstawione w miarę obiektywny sposób w jego wielotomowych wspomnieniach. Wiele dodatkowych informacji zawierają pamiętniki prezydenta Czechosłowacji E. Benesza, który starał się pośredniczyć między Churchillem a Stalinem. Jako przykład może tu służyć wyjątek ze wspomnień Churchilla odnotowany pod datą 6 stycznia 1944 r.: „Benesz był u mnie i jest pełen dobrych myśli w sprawie sytuacji w Rosji. Może on nam być bardzo pomocny w przemówieniu Polakom do rozsądku i pogodzeniu ich z Rosjanami, których zaufanie posiada od dawna. Przywiózł nową mapę ze znakami nakreślonymi ołówkiem przez Wuja Józefa, wyznaczającymi wschodnią granicę od Królewca do linii Curzona, co daje Polakom Łomżę i okręg białostocki na północy, lecz nie pozostawia im Lwowa na południu”. Sprawa polska podczas II wojny światowej w świetle pamiętników, oprac. S. Zabiełł, Warszawa 1958, s. 372. 
ustępstwem rządu polskiego była propozycja z 16 lutego 1944 r., czyli po przekroczeniu przez armię sowiecką przedwojennej wschodniej granicy Polski, na ustalenie linii demarkacyjnej przebiegającej pomiędzy granicami z traktatu ryskiego a linią demarkacyjną ustaloną w 1939 r. pozostawiającą Lwów i Wilno pod polską administracją. Sprzeciwiono się również włączeniu Królewca do ZSRR, co było już obiecane Stalinowi na konferencji teherańskiej. Nie było to obiektem większego zainteresowania trzech wielkich mocarstw, które w tej sprawie miały już stanowisko w zasadzie uzgodnione.

Postawa sowiecka została jeszcze raz przypomniana w styczniu 1944 r., kiedy to agencja TASS zakomunikowała oficjalnie, że: „wschodnie granice Polski mogą być ustalone na podstawie porozumienia ze Związkiem Sowieckim. Rząd sowiecki nie uważa granic z 1939 r. za niezmienne. Do granic tych mogą być wprowadzone poprawki na korzyść Polski, w tym kierunku by rejony, w których przeważa ludność polska oddane zostały Polsce. W tym wypadku granica sowiecko-polska mogłaby przebiegać mniej więcej według tak zwanej linii Curzona, którą w 1919 r. przyjęła Rada Najwyższa Mocarstw Sprzymierzonych i która przewiduje przyłączenie Ukrainy Zachodniej i Białorusi Zachodniej do Związku Sowieckiego"29. W ślad za oświadczeniem agencji TASS 12 stycznia 1944 r. w „Izwiestiach” ukazał się artykuł, w którym zamieszczono mapę pokazującą różnice między linią demarkacyjną z 1939 r. a linią Curzona (ryc. 4).

Ryc. 4. Linia Curzona według poglądu sowieckiego

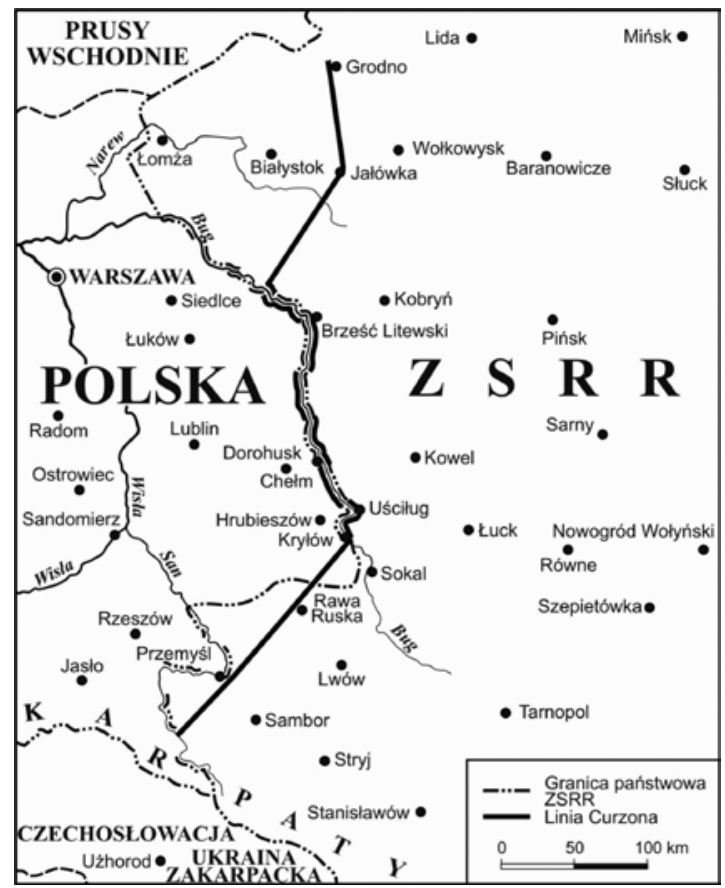

Opracowanie własne na podstawie:

Gazeta „Izwiestia” z 9.01.1944 r. Moskwa 1944.

${ }^{29}$ P. Eberhardt, Polska granica wschodnia, s. 127. 
Mając pełne poparcie mocarstw zachodnich w kwestii swojej granicy zachodniej, ZSRR rozpoczął działania mające na celu ustalenie w Polsce władzy, która zaakceptuje porozumienie graniczne między obu państwami. Z okupowanej Polski do Moskwy została zawezwana delegacja Krajowej Rady Narodowej, która wspólnie z utworzonym w ZSRR tzw. Związkiem Patriotów Polskich miała podpisać umowę o przyszłej granicy politycznej między Polską a ZSRR. Rozmowy na ten temat, w których ze strony polskiej wziął udział między innymi E. Osóbka-Morawski, B. Drobner i M. Rola-Żymierski, a ze strony sowieckiej Stalin, Mołotow i Wyszyński, odbyły się od 22 do 27 lipca 1944 r. Delegaci polscy przyjęli granice Curzona z włączeniem Lwowa do ZSRR jako granice wschodnie Polski. Na skutek wniosku Osóbki-Morawskiego ZSRR wyraził zgodę na odstąpienie Polsce części Puszczy Białowieskiej z Białowieżąą .

Granica polsko-sowiecka według linii Curzona nie tylko uzyskała już akceptację Wielkiej Brytanii i Stanów Zjednoczonych na konferencji teherańskiej, lecz także marionetkowych organizacji polskich, którym Stalin zamierzał przekazać władzę w Polsce. Pomimo tego sprawa nie była jeszcze całkowicie zamknięta, gdyż rząd polski w Londynie, nadal uznawany przez mocarstwa zachodnie, nie wyrażał zgody na dyktat graniczny. Było to powodem ingerencji Churchilla, który chciał zmusić rząd polski do wyrażenia zgody na linię Curzona. Obawiał się jego zmarginalizowania i objęcia władzy w Polsce przez ludzi dyspozycyjnych wobec Stalina. Były to już jedynie złudzenia, którym poddawał się Churchill. Na skutek nacisków tego ostatniego do Moskwy dwukrotnie udał się Mikołajczyk (3 sierpnia 1944 r. i 18 października 1944 r.). Na to drugie spotkanie udał się osobiście Churchill, aby być mediatorem między Mikołajczykiem a Stalinem. Rokowania te zakończyły się całkowitym fiaskiem, gdyż strona sowiecka nie była skłonna do żadnych ustępstw ani w kwestiach politycznych, ani granicznych. W trakcie pertraktacji Stalin złożył mało konkretną ofertę, a mianowicie powiedział: „Może uda się zrobić pewne zmiany w linii Curzona, które będą korzystne dla Polski. Nim to jednak nastąpi musi Pan dojść do porozumienia z Polakami z Lublina ${ }^{31}$ ”. Pozycja Mikołajczyka była słaba, gdyż miał przeciwko sobie Stalina, Churchilla oraz przedstawicieli PKWN. Zdając sobie sprawę z krytycznej

${ }^{30}$ W pamiętnikach E. Osóbki-Morawskiego ten epizod został odnotowany w sposób następujący: „Na sam koniec dyskusji ze Stalinem zostawiłem sprawę Puszczy Białowieskiej, która według projektu Mołotowa miała przypaść w całości Związkowi Radzieckiemu. Argumentowałem, że jest to nasz park narodowy i teren, gdzie nasi powstańcy wielokrotnie walczyli o niepodległość kraju. Ponadto zwracałem uwagę, że Polska ma bardzo przetrzebione lasy przez okupanta, a puszcza stanowi jedyne zaplecze surowcowe dla przemysłu w Hajnówce. Wreszcie nie istniał tam problem narodowościowy, który był przecież głównym powodem zmiany polskich granic wschodnich”. Ta argumentacja nie w pełni usatysfakcjonowała Stalina, ale Osóbka-Morawski w gronie polskiej delegacji zagroził dymisją ze stanowiska przewodniczącego PKWN. Wpłynęło to na decyzję strony sowieckiej, gdyż Osóbka-Morawski wspomina: „Po upływie około pół godziny zatelefonował do mnie Mołotow i oświadczył, że Stalin zgodził się na przyłączenie do Polski połowy Puszczy z Białowieżą włącznie. Sprawa granicy została ustalona”, E. Osóbka-Morawski, Trudna droga. Fragmenty wspomnień, Redakcja „Tydzień Robotnika”, Warszawa 1992, s. 122-123.

${ }^{31}$ S. Mikołajczyk, Polska zgwałcona, Warszawa 1986, s. 83-84. 
sytuacji i osamotnienia, zgodził się ostatecznie na duże straty terytorialne dla ratowania Lwowa. Pod wpływem presji Mikołajczyk przyjął jako punkt wyjścia do pertraktacji linię Curzona. Jednak zgodnie z ustaleniami z 1919 r. wyraził zgodę na przebieg granicy wzdłuż linii Curzona na odcinku północnym i środkowym, tzn. w rejonie Grodna, Puszczy Białowieskiej oraz na odcinku Bugu dochodzącym do Sokala. Natomiast na odcinku południowym przechodzącym przez terytorium Galicji Mikołajczyk wyraził gotowość przyjęcia tzw. linii „B”, przebiegającej na wschód od Lwowa, względnie zaproponował ujęcie alternatywne, $w$ którym linia „B” miała być granicą, $w$ drugim zaś wariancie linia „A” przebiegająca w bezpośrednim sąsiedztwie Przemyśla będzie traktowana jako tymczasowa linia demarkacyjna ${ }^{32}$. Postulaty te były już zignorowane. Żądano od Mikołajczyka pełnej kapitulacji. Nie wyraził na to zgody. Wizyta Mikołajczyka w październiku 1944 r. zakończyła się niepowodzeniem. Rząd polski w Londynie, nie mając wsparcia u żadnego z wielkich mocarstw, znalazł się w pełnej izolacji politycznej. W przemówieniu wygłoszonym w Izbie Gmin 15 grudnia 1944 r. Churchill wyraźnie opowiedział się za wariantem granicznym mniej korzystnym dla Polski, tzn. za linią Curzona „A” oddającą Lwów i Zagłębie Naftowe ZSRR ${ }^{33}$.

Drugie spotkanie szefów rządów trzech wielkich mocarstw odbyło się w dniach 4-11 lutego 1945 r. w Jałcie na Krymie. Nie jest celowe komentowanie dyskusji odbywającej się w Pałacu Liwadyjskim, gdyż było to już wielokrotnie omawiane w literaturze przedmiotu. Wiadomo, że Stalin i Churchill stanęli na stanowisku wyznaczenia granicy wschodniej Polski według niekorzystnego dla niej wariantu „A”. Stanowisko Roosvelta było mniej stanowcze, gdyż zwrócił się do Stalina z prośbą o ponowne rozpatrzenie południowego odcinka linii Curzona, ale dodał jednocześnie, że nie jest to kwestia ważna i pozostawia decyzję stronie sowieckiej. Przy tego typu fakultatywnym postawieniu sprawy stanowisko Stalina nie było poważnie zagrożone i ostatecznie przyjęto $\mathrm{z}$ aprobatą sowiecki wariant linii Curzona ${ }^{34}$.

${ }^{32}$ Stanowisko Stalina było bezkompromisowe i wykorzystał jeszcze raz te argumenty, które w pełni aprobowały mocarstwa zachodnie. Warto je jeszcze raz przypomnieć: „Linia demarkacyjna to nie jest granica. Ja stanowczo obstaję przy natychmiastowym ustaleniu granic, które, tak jak poprzednio mówiłem, mają biec wzdłuż linii Curzona. Zresztą, jeśli chodzi o linię Curzona, to nie była ona wymyślona przez nas, ale przez ówczesnych sojuszników. Była „odobriena” przez Amerykanów, Francuzów, Anglików. Przez naszych ówczesnych wrogów. My od linii Curzona odstąpić nie możemy. Curzon był wrogiem naszym i Clemenceau także. Jeżelibyśmy zrobili odstępstwa od tej linii, to byłoby nam wstyd tego. Dlatego też zrobić tego nie możemy. Tereny te były zawsze przedmiotem starć i walk między Polakami, Białorusinami i Ukraińcami i to raz na zawsze musi się skończyć. Kto chce pokoju, musi to przyjąć. Zresztą, jeżeli chodzi o naród polski, on nie będzie się przeciwstawiać temu. Przedstawiciele Komitetu Lubelskiego p.p. Bierut i Osóbka oświadczyli mi, że nowa granica jest sprawiedliwa" (Sprawa polska w czasie drugiej wojny, s. 606-607).

${ }^{33}$ Ibidem, s. 648-649.

${ }^{34}$ Informacje, które dotarły do Polaków w kraju i za granicą, o pełnej akceptacji przez Stany Zjednoczone i Wielką Brytanię polskiej granicy wschodniej według linii Curzona zostały potraktowane jako akt krzywdzący, mający znamiona zdrady. Można to odczytać z opracowania: A. Wolmar, Dyktat Krymski musi być unieważniony, Palestyna 1945. 
W ostatecznym komunikacie wydanym 11 lutego 1945 r. zawarto uzgodnione stanowisko trzech wielkich mocarstw. Brzmiało ono następująco: „Szefowie trzech rządów uważają, że wschodnia granica Polski powinna biec wzdłuż linii Curzona z odchyleniem od niej w pewnych okolicach o pięć do ośmiu kilometrów na korzyść Polski”. Pomimo że w dokumencie końcowym nie podano, jak należy rozumieć przebieg linii Curzona, to jednak nie było już wątpliwości, że granica będzie przebiegała według wariantu najmniej korzystnego dla Polski, tzn. według linii „A” z pozostawieniem Lwowa po stronie Związku Sowieckiego. O nieodwracalności decyzji świadczył fakt, że - w odróżnieniu od zachodniej granicy Polski - nie miała o niej wyrokować w przyszłości konferencja pokojowa ${ }^{35}$.

Następna, trzecia konferencja przywódców Związku Sowieckiego, Stanów Zjednoczonych i Wielkiej Brytanii odbyła się w Poczdamie i trwała trzy tygodnie (17 lipca - 2 sierpnia 1945 r.). Miała ona ostatecznie rozstrzygnąć przebieg polskiej granicy zachodniej, która w Jałcie była rozważana w sposób bardzo ogólny i bez przyjęcia definitywnych rozstrzygnięć. Na konferencji w Poczdamie problematyka polskiej granicy wschodniej nie była podawana w wątpliwość. Decyzje, które zapadły w tej sprawie w Jałcie, nie były kwestionowane i przedstawiciele trzech wielkich mocarstw zaakceptowali je w pełnym zakresie. Niemniej problem utraty ziem wschodnich przez Polskę na rzecz ZSRR był jednym z ważniejszych argumentów uzasadniających uzyskanie przez Polskę rekompensaty na zachodzie.

Decyzje podjęte w Jałcie odniesione do granicy polsko-sowieckiej wymagały procedury delimitacyjnej, gdyż poprzednia umowa zawarta 26 lipca 1944 r. między rządem sowieckim a delegacją Polskiego Komitetu Wyzwolenia Narodowego nie była $\mathrm{z}$ punktu widzenia prawa międzynarodowego aktem wiążącym i prawomocnym. W pierwszej połowie sierpnia 1945 r. do Moskwy przybyła delegacja rządowa z Bierutem, Osóbką-Morawskim, Mikołajczykiem, Mincem oraz szerokim gronem ekspertów, m.in. S. Leszczyckim i A. Bolewskim. Zespół specjalistów przygotował graniczne rozwiązania wariantowe od bardziej maksymalistycznych po bardziej skromne, zmierzające do pewnych korekt ustalonej granicy. Strona sowiecka zajmowała stanowisko bezkompromisowe. Niemniej polscy eksperci starali się zminimalizować straty i uzyskać pewne weryfikacje na korzyść Polski ${ }^{36}$.

Przy odcinku północno-wschodnim, między Kanałem Augustowskim a Jałówką, polscy negocjatorzy domagali się ustalenia granicy zgodnie z linią Curzona, która

${ }^{35}$ W czasie, gdy kwestia przyjęcia linii Curzona jako wschodniej granicy Polski była aktualna i rozważana, w prasie światowej ukazały się dwie anglojęzyczne publikacje polskich autorów, które traktowane są jako ujęcie klasyczne: K. Smogorzewski, About the Curzon Line and others lines, London 1944 oraz L. Kirkien, Russia, Poland and the Curzon Line, Edinburgh 1945. Równolegle ukazała się publikacja w języku niemieckim: Die Curzon-Linie. Das Grenzproblem Sowjetunion-Polen, Zürich/New York 1945. W późniejszym czasie geneza i konsekwencje geopolityczne przyjęcia linii Curzona nie budziły na Zachodzie większego zainteresowania geografów i historyków.

${ }_{36}$ Problematyka ta została omówiona w artykule uczestnika konferencji moskiewskiej (S. Leszczycki, Ważyły się w 1945 roku losy Bieszczadów, „Miesięcznik Ziem Górskich”, nr 12, Warszawa 1992). 
dochodziła do Niemna na północ od Grodna i nurtem rzeki dochodziła do Łosośny. Propozycja ta została odrzucona. Obie strony inaczej interpretowały linię Curzona. Pomimo wyraźnej tendencyjności w argumentacji sowieckiej nie udało się tu nic zmienić. Stronie sowieckiej zależało na fortyfikacjach usytuowanych po zachodniej stronie Niemna broniących dostępu do Grodna. Uznano natomiast w pełni przesunięcie granicy na wschód w rejonie Puszczy Białowieskiej. Największe kontrowersje budził przebieg południowego odcinka linii granicznej między Kryłowem a Karpatami. Polsce odstąpiono tzw. kolano Bugu aż do Krystynopola, gdyż ten obszar w latach 1939-1941 należał do Generalnego Gubernatorstwa. Długa polemika dotyczyła przynależności politycznej stacji kolejowej Chyrów, która łączyła dwie polskie równoleżnikowe magistrale kolejowe. Wszelkie polskie argumenty zostały odrzucone. Udało się odzyskać kilka miejscowości w pobliżu Przemyśla (w tym nadgraniczną Medykę) oraz dzięki zaangażowaniu polskiego eksperta Leszczyckiego niewielki rejon Bieszczad, położony na wschód od Ustrzyk Górnych z Tarnicą i Haliczem. Większość polskich wniosków została brutalnie odrzucona. Negocjatorzy sowieccy nie respektowali jednego z zaleceń umowy jałtańskiej wskazującego na możliwość przesunięcia granicy Curzona od 5 do $8 \mathrm{~km}$ na korzyść Polski. Pilnowali przebiegu linii prostej między miejscowościami podanymi w telegramie Curzona z 1919 r. To były dla nich jedyne wytyczne, których konsekwentnie przestrzegali przy ostatecznej delimitacji granicy (ryc. 5).

Końcowym wynikiem obrad było podpisanie przez Osóbkę-Morawskiego i Mołotowa 16 sierpnia 1945 r. umowy o granicy państwowej między Polską a ZSRR. Były w niej tylko niewielkie odstępstwa od historycznej linii Curzona. Zaznaczono w jej treści, że ZSRR odstępuje Polsce dodatkowo:

- obszar położony na wschód od linii Curzona do rzeki Bug i Sołokija, na południe od miasta Kryłów z odchyleniem na rzecz Polski nieprzekraczającym 30 kilometrów ${ }^{37}$;

- część obszaru Puszczy Białowieskiej na odcinku Niemirów-Jałówka, leżącego na wschód od linii Curzona, łącznie z Niemirowem, Hajnówką, Białowieżą i Jałówką z odchyleniem na rzecz Polski nieprzekraczającym 17 kilometrów.

W następnej części dokumentu dokładnie opisano granicę według punktów topograficznych. Ponadto wykreślono $\mathrm{w}$ formie linii prostej granicę między Polską a ZSRR na obszarze Prus Wschodnich. Została ona wyraźnie wygięta na odcinku środkowym. Dzięki temu Gierdawy i Pruska Iławka znalazły się po północnej stronie rozgraniczenia.

\section{Uwagi końcowe}

Ustalenie granicy wschodniej według linii Curzona przyniosło w rezultacie utratę przez Polskę 179 tys. $\mathrm{km}^{2}$. Stanowiło to $46,1 \%$ przedwojennego terytorium państwa polskiego (ryc. 6). Stało się to pomimo stania od pierwszego do ostatniego dnia

37 Wskazany obszar był w granicach Polski do 15 lutego $1951 \mathrm{r}$. W tym roku nastąpiła wymiana terytoriów między ZSRR a Polską o powierzchni $480 \mathrm{~km}^{2}$. Polska utraciła ten obszar, a uzyskała rejon o identycznej powierzchni w okolicach Ustrzyk Dolnych. 


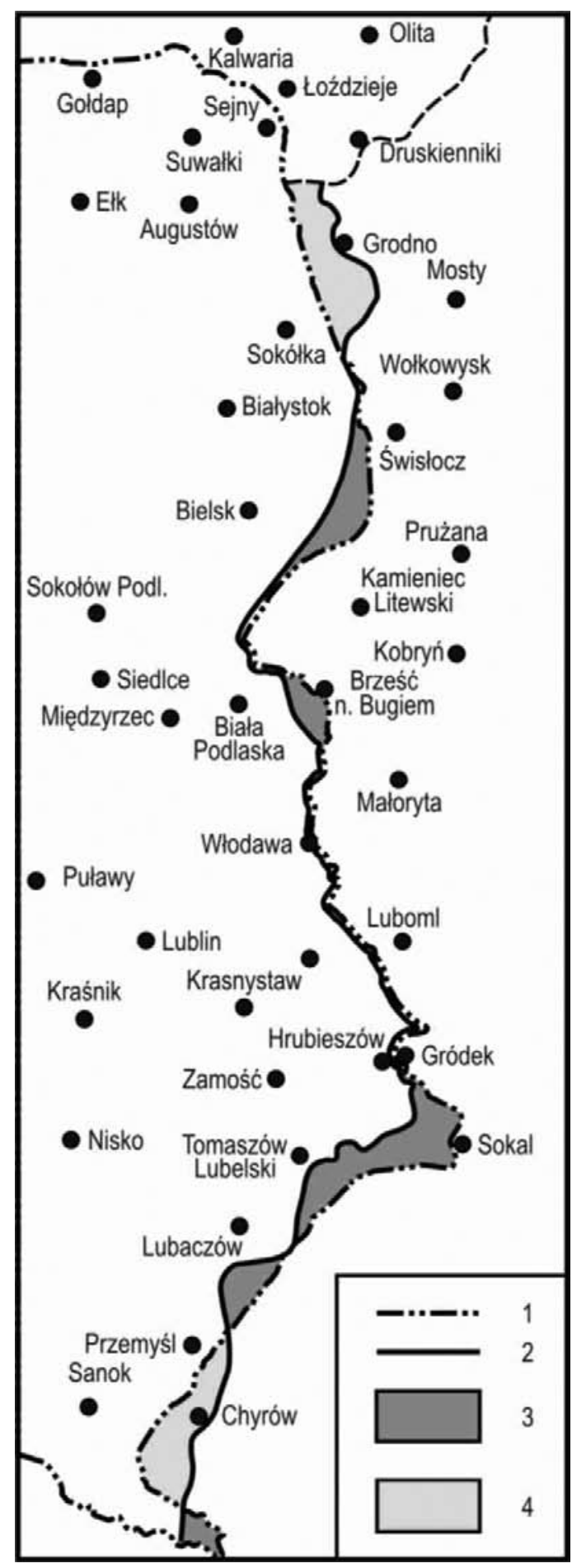

Ryc. 5. Powojenna wschodnia granica Polski oraz linia Curzona

1 - granica wschodnia Polski po Il wojnie światowej, 2 - linia Curzona,

3 - obszary włączone do Polski położone na wschód od linii Curzona,

4 - obszary niewłączone do Polski położone na zachód od linii Curzona

Opracowanie własne na podstawie: Historyczny Atlas Polski, Warszawa 2009, s. 112. 
wojny po stronie sprzymierzonych i znalezienia się po w obozie zwycięskiej koalicji. Nie można jednak pomijać faktu, że Polska uzyskała bardzo istotną rekompensatę terytorialną na zachodzie o powierzchni 102,8 tys. $\mathrm{km}^{2}$.

Ryc. 6. Wschodnia granica Polski (1921-1939 oraz po 1945 r.)

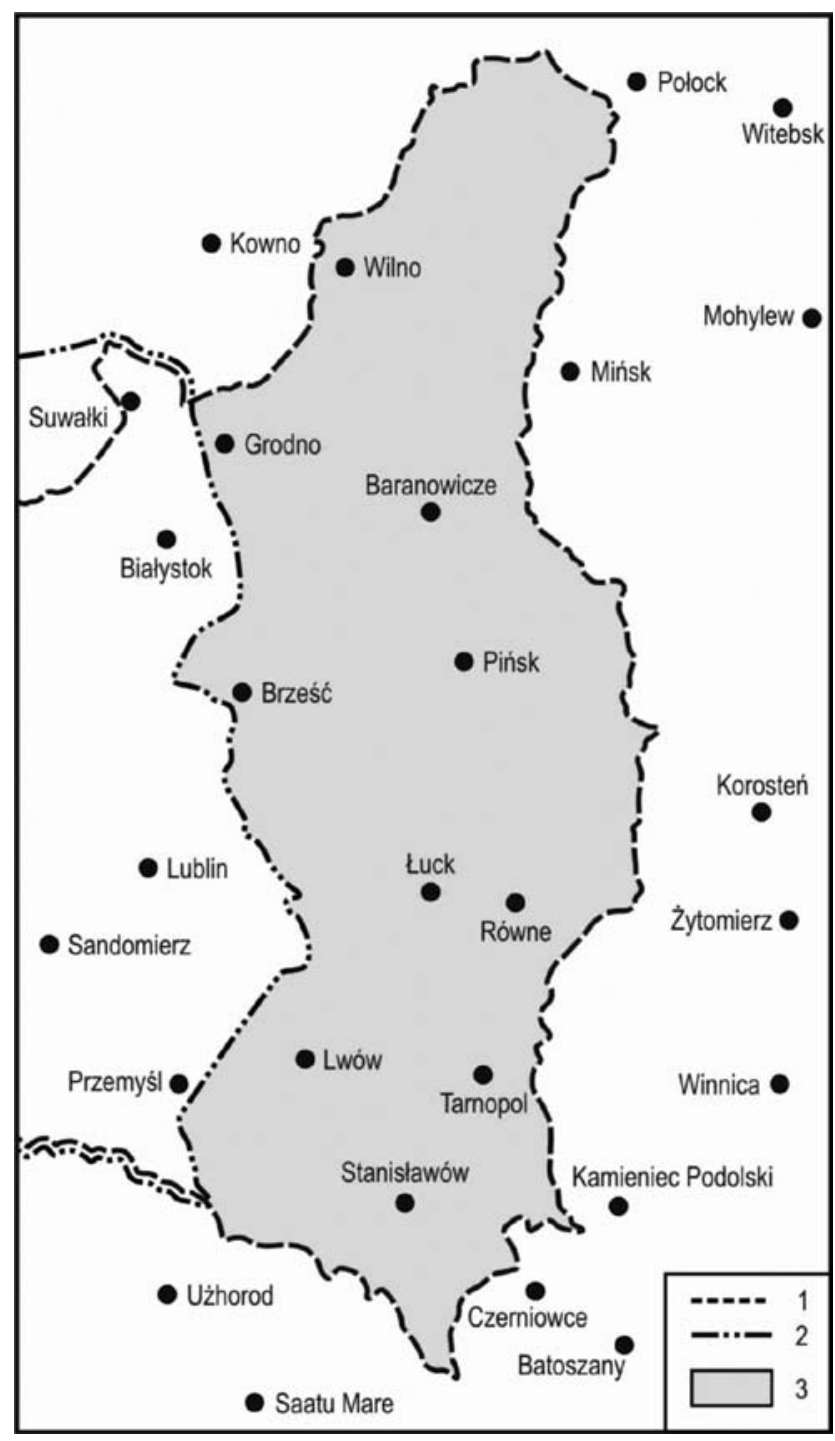

1 - wschodnia granica Polski wg traktatu rosyjskiego z 18 marca 1921 r.,

2 - wschodnia granica Polski wg układu polsko-sowieckiego z 16 sierpnia 1945 r.,

3 - ziemie II Rzeczypospolitej utracone na rzecz ZSRR.

Opracowanie własne na podstawie: Historyczny Atlas Polski, Warszawa 2009, s. 112. 
Podpisana umowa graniczna przekreśliła jednak definitywnie i jednoznacznie umowę rozbiorową zawartą między Ribbentropem a Mołotowem. W stosunku do linii demarkacyjnej istniejącej od 28 września 1939 r. do 22 czerwca 1941 r. nastąpiły wyraźne zmiany na korzyść Polski, które wyniosły 22 tys. km².

Wydarzenia II wojny światowej przypieczętowane utratą ziem wschodnich były dla Polski radykalnym zerwaniem z przeszłością. Dla wielu pokoleń Polaków miasta takie jak Grodno, Wilno czy Lwów były tak samo polskie, jak Warszawa, Kraków czy Lublin. Kresy Wschodnie od 600 lat związane były z Polską, nawet w czasie zaborów były uważane przez społeczeństwo polskie jako obszar polski. Na terytoriach, które Polska utraciła znajdowały się dwa wielkie ośrodki kultury polskiej (Wilno i Lwów). Prawdą jest, że Polacy stanowili na straconym obszarze 1/3 ogółu zaludnienia, ale byli główną warstwą pod względem tradycji narodowych, wykształcenia i kultury.

W rezultacie utraty ziem wschodnich oraz uzyskania poważnej rekompensaty na zachodzie państwo polskie powstało w nowym, całkowicie odmienionym kształcie terytorialnym. Po wielkich przesiedleniach ludności Polska stała się państwem jednorodnym narodowościowo. Trudno ocenić ogólne salda strat i zysków. Miastami polskimi stały się: Wrocław, Szczecin, Gdańsk i Olsztyn. Ponadto Polska uzyskała szeroki dostęp do morza. Granica wschodnia Polski przesunęła się daleko na zachód $\mathrm{z}$ rozgraniczenia ustalonego $\mathrm{w}$ traktacie ryskim na linię Curzona, ale jednocześnie granica zachodnia przesunęła się z granicy ustalonej w traktacie wersalskim na linię Odry i Nysy Łużyckiej. Z tego powodu oceniając konsekwencje ustalenia polskiej granicy wschodniej według linii Curzona, koniecznie trzeba uwzględniać całościowy bilans zmian terytorialnych, których ostatecznym efektem było powstanie Polski w granicach jałtańsko-poczdamskich.

The Curzon line as Poland's eastern border - origin and political conditions

The article is devoted to the forming of the contemporary eastern border of Poland, named in the subject literature "the Curzon line". Its geographical location was put forward by Lord Curzon, British Foreign Minister at the time. It was not put to practice then. The conception was raised again during the last stage of World War II, and, since 1945, the Curzon line has been the eastern border of Poland.

The first part of the article discusses the complex political, demographic, and national conditions on the area located between ethnic Poland and ethnic Russia, which until 1772 belonged to Poland, and later, during the three partitions were attached to the Russian Empire. Both countries were convinced about their justified historical rights to the territories being the meeting point of their geopolitical interests; setting a border to both Moscow's and Warsaw's satisfaction was unlikely.

The next part of the article presents the political situation after the end of World War I, as well as the view of western countries (France, Great Britain, The USA) on the territorial range of the newly formed Polish country. The western Polish borders were settled at the peace conference in Versailles; the eastern borders, on the other hand, depended on the inevitable military conflict between Poland and Bolshevik Russia. The conflict lasted for two years and ended in signing Riga Treaty on March 18, 1921. The treaty established the new borders between the two countries. The possibilities of an intervention of the Ententa countries in the war were relatively small; they did, however, try to lead them to a political agreement 
through diplomatic negotiations. They were not interested in the defeat of Poland. They were also quite critical about maximalistic territorial demands presented by Poland. During the 1918-1920 war, Britain proposed a solution that et the border meridionally, from Grodno in the north to the Karpaty in the south, and ran through Jałówka, Niemirów and Kryłów. The project received the name of "the Curzon line". The article presents the beginnings of the concept, its authors, as well as the military and political circumstances, which made the realization of the idea impossible at the time.

The subsequent part of the article discusses the geopolitical situation after Ribbentrop-Molotow pact (1939-1941), and after the German invasion on the USSR, the focal point being the verdicts passed at three great conferences of the anti-Hitlerite coalition countries in Teheran and Jałta, where Polish eastern border was decided upon without being accepted by Poland. The location of the border was based on Lord Curzon's suggestion of 1919, and was realized after World War II. It required only technical delimitation settlements. As a result of decisions made in Poczdam, the western border was relocated on the line of the Odra and the Nysa Łużycka. The Riga - Versailles Poland was replaced by one shaped by Jałta and Poczdam. The aforementioned border changes are analysed from a historical and geographical perspective.

\section{Линия Керзона - восточная граница Польши - генезис и политические условия.}

Статья посвящена формированию современной восточной границы Польши, которую в литературе общепринято называть линией Керзона. Проект прохождения этой линии был представлен в 1919 г тогдашним министром иностранных дел Великобритании лордом Керзоном, но в те времена так и не был реализован. Очередной раз об этой линии вспомнили в конечной фазе Второй мировой войны, а с 1945 г она становится восточной границей польского государства.

В первой части статьи освещается сложная политическая и национально-демографическая ситуация на территории, расположенной между этнической Польшей и этнической Россией, которая до 1772 г принадлежала I Речи Посполитой, а потом в течение трех разделов была присоединена к Российской Империи. Оба государства были убеждены, что у них есть все законные исторические права на эту территорию, лежавшую на стыке их геополитических интересов. Посему определение восточной границы, удовлетворявшей интересы как Варшавы, так Москвы являлось малоправдоподобным.

В следующей части статьи обсуждается политическая ситуация после окончания Первой мировой войны и позиция западных держав (Франции, Великобритании, США) по вопросу только что созданного польского государства. Западные границы Польши были установлены на конференции в Париже. Восточные же границы зависели от итогов военного конфликта между Польшей и большевистской Россией. Он продолжался два года и закончился подписанием Рижского мирного договора (18 марта 1921 г), который очертил новые границы между двумя государствами. Возможности влияния стран-участниц Антанты на ход и результаты этой войны были относительно невелики. Тем не менее, западные державы предпринимали попытки дипломатическим путем привести оба государства к политическому компромиссу. Они не были заинтересованы поражением Польши, хотя достаточно критично оценивали ее максималистские желания, касающиеся восточной границы. Британская сторона во время войны 1918-1920 гг. предложила разграничение границ, которое проходило от Гродно на севере до Карпат на юге через Яловку, Немиров и Крылов. Проект этот, как уже вспоминалось выше, был назван линией Керзона. В статье описывается генезис этой концепции, ее авторы, военные и политические условия, приведшие к тому, что она в тогдашних условиях не была реализована.

В очередной части статьи описана геополитическая ситуация после заключения пакта Риббентропа- Молотова (1939-1941), а в последствии после агрессии Германии на СССР . В статье уделяется большое внимание решениям, принятым на конференциях 3-х великих держав 
антигитлеровской коалиции в Тегеране и в Крыму. На этих конференциях без согласия польской стороны было принято решение о прохождении восточной польской границы, которая напоминала концепцию лорда Керзона, выдвинутую в 1919 г. После окончания Второй мировой войны была она претворена в жизнь. Требовалось только проведение технических делимитационных работ. Одновременно с изменением восточной границы Польши в результате решений Постдамской конференции были изменены западные границы Польши на линии Одер - Ныса Лужицкая. На месте версальско-рижской Польши появилось польское государство с границами ялтинско-постдамскими. В статье изменения границ интерпретируются в географическом и историческом контексте 